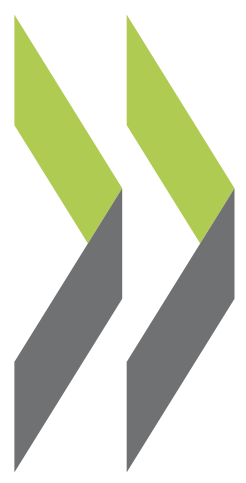

OECD Economics Department Working Papers No. 1030

The System of Revenue Sharing and Fiscal Transfers in China

Xiao Wang,

Richard Herd 
Organisation de Coopération et de Développement Économiques

Organisation for Economic Co-operation and Development

27-Feb-2013

ECONOMICS DEPARTMENT

English - Or. English

THE SYSTEM OF REVENUE SHARING AND FISCAL TRANSFERS IN CHINA

ECONOMICS DEPARTMENT WORKING PAPERS No. 1030

By Xiao Wang and Richard Herd

All Economics Department Working Papers are available through OECD's Internet website at http://www.oecd.org/eco/workingpapers

JT03335369

Complete document available on OLIS in its original format

This document and any map included herein are without prejudice to the status of or sovereignty over any territory, to the delimitation of international frontiers and boundaries and to the name of any territory, city or area. 


\section{ABSTRACT/RÉSUMÉ}

\section{The system of revenue sharing and fiscal transfers in China}

The main features of China's current sub-national finance arrangements date back to the 1994 tax reform. China has a multi-level government structure that shares national tax revenues through a system of tax sharing and transfers, and divides spending assignments and responsibilities. Local governments have hardly any discretionary power to modify taxation, though they have some non-tax revenue from fees, levies and penalties. They can also spend the profit from the sale of land-use rights subject to central government restrictions. As the 1994 tax reform recentralised revenues and decision-making power, vertical gaps between revenue and expenditure at sub-national levels have grown. In order to accommodate this, the central government has raised the scale of transfers. Over the past decade, China's transfer policy has addressed the horizontal imbalances and become markedly more redistributive. Nevertheless, fiscal disparities within provinces remain high and are much greater than between regions in OECD countries. The extent of fiscal equalisation within provinces varies, thus affecting the delivery of services. The government's plan to equalise service provision across the country therefore calls for fine-tuning the transfer system and improving local revenue. Some local governments are testing a residential property tax but not in a form that would substantially raise tax revenue. A significant property tax would tend to lower the revenue from the sale of land-use rights and would, in general, improve the fiscal position of those local governments that already have strong budgets.

This Working Paper relates to the 2013 OECD Economic Survey of China (www.oecd.org/eco/surveys/china)

JEL classification: H71, H72, H73, H74, H77, H11, H24, H25, H27, H51, H52, H60, H61, D63, E62, R52.

Keywords: China, public finance, tax sharing, fiscal disparities, intergovernmental transfers, local government, service equalisation, land-use rights, property taxation.

$* * * * * * * * * * * * * * * * * * * * * * * * *$

\section{Le système de partage des recettes et des transferts budgétaires en Chine}

Les principales caractéristiques des accords de financement infranationaux actuels en Chine remontent à la réforme fiscale de 1994. La Chine possède une structure administrative à plusieurs niveaux qui partage les recettes fiscales nationales par le biais d'un système de répartition des recettes fiscales et de transferts, et qui attribue les missions et responsabilités en matière de dépense. Les collectivités locales n'ont guère de pouvoir discrétionnaire afin de modifier la fiscalité, même si elles collectent des recettes non fiscales provenant de divers droits, prélèvements et amendes. Elles peuvent aussi dépenser les recettes provenant de la vente de droits d'usage des terrains sous réserve de restrictions imposées par le gouvernement central. Comme la réforme fiscale de 1994 a centralisé de nouveau les recettes et le pouvoir de décision, les déséquilibres verticaux entre recettes et dépenses au niveau infranational se sont accentués. Afin d'en tenir compte, le gouvernement central a augmenté le volume des transferts. Au cours de la décennie passée, la politique des transferts en Chine a répondu aux déséquilibres horizontaux et est devenue nettement plus redistributive. Néanmoins, les disparités fiscales au sein des provinces demeurent élevées et sont beaucoup plus grandes qu'entre régions des pays de l'OCDE. Le degré de péréquation au sein des provinces varie, ce qui affecte la prestation de services. Afin d'égaliser cette dernière dans tout le pays, le plan du gouvernement appelle donc à peaufiner le système de transferts et à améliorer les recettes locales. Certaines autorités locales sont en train de tester un impôt foncier résidentiel, mais pas sous une forme qui permettrait d'augmenter considérablement les recettes fiscales. Un impôt foncier important aurait tendance à réduire les recettes provenant de la vente de droits d'usage des terrains et, plus généralement, améliorerait la situation financière des administrations locales déjà dotées de solides budgets.

Ce Document de travail a trait à l'Étude économique de l'OCDE de la Chine, 2013 (www.oecd.org/eco/etudes/chine). Classification JEL : H71, H72, H73, H74, H77, H11, H24, H25, H27, H51, H52, H60, H61, D63, E62, R52.

Mots clés: Chine, finances publiques, répartition des recettes fiscales, les disparités fiscales, les transferts intergouvernementaux, les collectivités locales, égalisation service, droits d'usage des terrains, impôt foncier.

(C) OECD (2013)

You can copy, download or print OECD content for your own use, and you can include excerpts from OECD publications, databases and multimedia products in your own documents, presentations, blogs, websites and teaching materials, provided that suitable acknowledgment of OECD as source and copyright owner is given. All requests for commercial use and translation rights should be submitted to rights@oecd.org 


\section{TABLE OF CONTENTS}

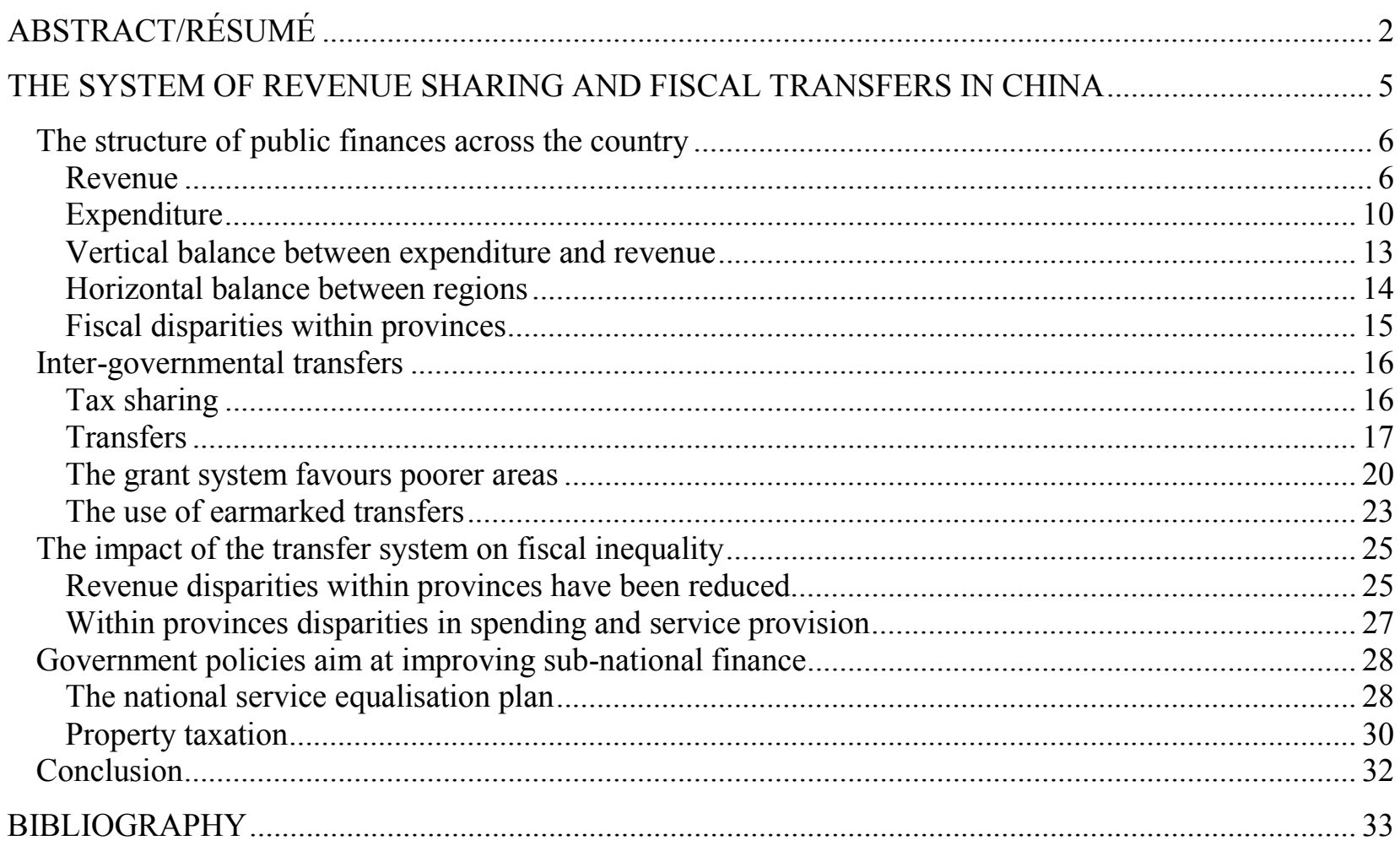

\section{Tables}

1. Revenue assignments and actual revenue for central and local government................................ 7

2. Distribution of tax sources by level of sub-national government .............................................. 9

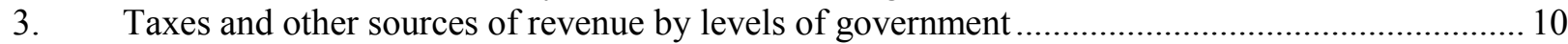

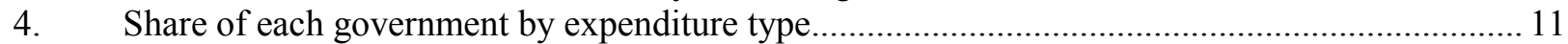

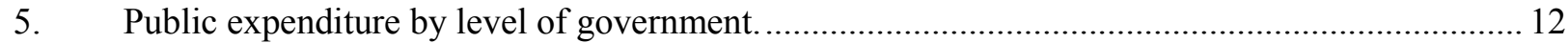

6. Balance between expenditure and the sum of tax and non-tax revenues...................................... 13

7. Regional inequality in China and selected OECD countries .................................................... 14

8. Dispersion of different tax and non-tax revenues across provinces ...................................... 15

9. Revenue imbalances at different levels of government ....................................................... 16

10. Fiscal disparity reducing effect of transfers in OECD countries and in China............................2 25

11. The impact of transfers at sub-provincial levels on inequality of revenue.................................... 26

12. The $12^{\text {th }}$ Five Year Plan for basic public service equalisation and urbanisation ..........................2 29

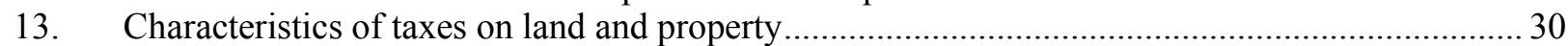

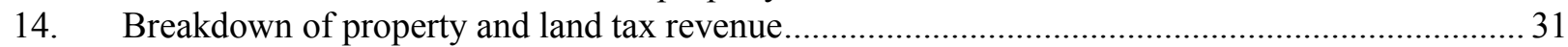




\section{Figures}

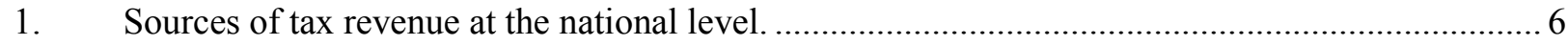

2. Local tax-setting: the local taxes under the control of local governments .................................. 7

3. The importance of various taxes assigned to local government .................................................. 8

4. Central and local government expenditure as share of GDP .................................................. 13

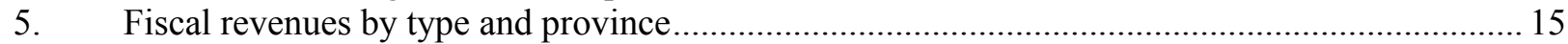

6. Strict tax sharing and other forms of sub-national government revenue.................................... 17

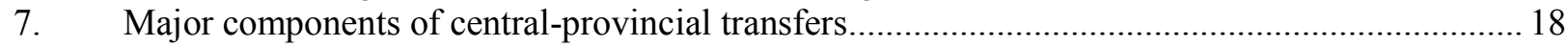

8. Different types of transfers as a share of national tax revenues .............................................. 19

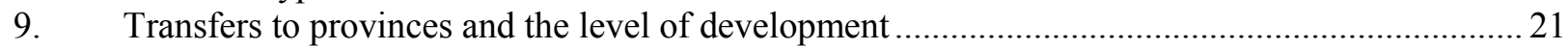

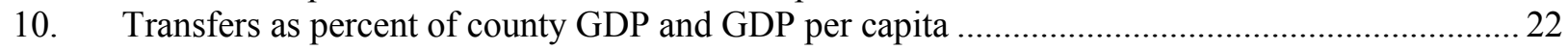

11. Central to province transfers and provincial GDP per capita ......................................................2 23

12. Composition of grants for states/provinces in OECD countries..................................................24

13. Composition of grants to local/sub-provincial level in OECD countries and China.................... 24

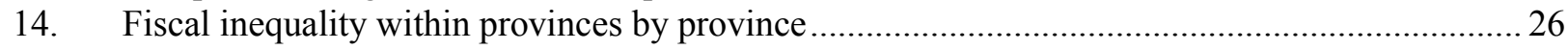

15. The reduction of intra-provincial fiscal inequality and the initial level of the inequality .............27

16. Dispersion of government spending and employment across and within provinces.....................28

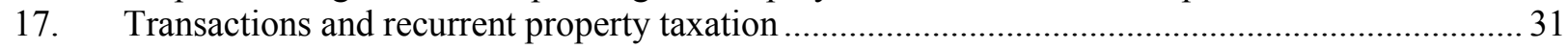

\section{Boxes}

Box 1. China's administrative divisions..... 5

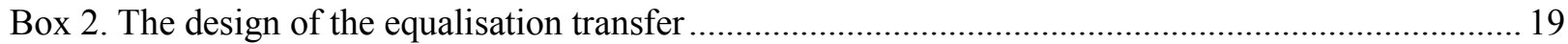


ECO/WKP(2013)22

\title{
THE SYSTEM OF REVENUE SHARING AND FISCAL TRANSFERS IN CHINA
}

\author{
Xiao Wang and Richard Herd ${ }^{1}$
}

This paper presents the main features of China's sub-national public finance arrangements and discusses past and potential changes that affect fiscal disparities across the country. China has a multitiered government structure (Box 1) that shares overall national tax revenues through tax sharing and transfers. The paper first outlines the distribution of revenue and expenditure by level of government. It then discusses how transfers affect fiscal inequality. After considering the orientation of government policy in service equalisation, the paper looks at the government's plans to improve sub-national finance.

\section{Box 1. China's administrative divisions}

The administrative structure of the People's Republic of China has four sub-national levels: provincial, prefectural, county and township. The People's Assembly at each level reports to the assembly at the next higher level. Finally, the provincial assembly reports to the national assembly. There is also an informal level of government below the township level called the village level. In parallel to the government structure, there is a similar structure for the Communist Party. The names of each level of government vary across the country.

The provincial level can be known as a province, an autonomous region or a municipality (these are generally large cities under the direct control of the national assembly - the case for Beijing, Shanghai or Tianjin, or part of a former larger province as in the case of Chongqing). In the rest of this paper, all provincial-level governments are referred to as provinces.

At the prefectural level, there are three types of government: prefectures, prefectural-level cities and subprovincial-level cities. The distinction between the first two depends on the level of urbanisation, while the latter consists of a small group of cities that are able to bypass the provincial government and deal directly with national government in certain areas. Municipalities do not have the prefectural level of government.

At the county level, there are three types of institution: districts, county cities and counties which again can have varying names across the country. Districts are urban areas of a prefectural-level city. Counties are generally rural areas, though some have an urban character. County cities are counties that had an urban core of above a certain size before 2000 .

Finally, the township is lowest level of administration. In the urban areas of prefectural-level cities, this unit is known as a sub-district. Elsewhere, it is known as a town or township depending on its size. There also exists a unit below the township level known as a village in rural areas or neighbourhood in urban areas. They have no official administrative role but serve as a channel of communication to the population.

\begin{tabular}{|c|c|c|c|c|}
\hline Provincial level & Prefectural level & County level & Township level & $\begin{array}{c}\text { Village } \\
\text { level (informal) }\end{array}$ \\
\hline 31 & 332 & 2853 & 40466 & around 900000 \\
\hline $\begin{array}{l}\text { Provinces, } 22 \\
\text { Autonomous regions, } 5 \\
\text { Municipalities, } 4\end{array}$ & $\begin{array}{l}\text { Cities, } 284 \\
\text { Prefectures, } 48\end{array}$ & $\begin{array}{l}\text { Districts, } 857 \\
\text { County cities, } 369 \\
\text { Counties, } 1573\end{array}$ & $\begin{array}{l}\text { Streets, } 7194 \\
\text { Towns, } 19683 \\
\text { Townships, } 13857\end{array}$ & \\
\hline
\end{tabular}

Note: Following the practice of the China Statistical Yearbook, these statistics cover mainland China only. Source: China Statistical Yearbook 2012; Ministry of Civil Administration.

1. Xiao Wang was an economist (Consultant) working on the China Desk in the Economics Department of the OECD in 2012 and early 2013, and Richard Herd is the head of the Desk. This paper was prepared as background analysis for the 2013 OECD Economic Survey of China. The authors are grateful for useful feedback from Yong Zheng and Jidong Yuan at the Chinese Ministry of Finance, and from Vincent Koen, Robert Ford, Hansjörg Blöchliger and Bert Brys at the OECD. Thomas Chalaux provided excellent technical assistance and Nadine Dufour and Pascal Halim editorial assistance. 


\section{The structure of public finances across the country}

\section{Revenue}

The current tax system was put in place in 1994. A value-added tax (VAT) on goods replaced scores of cascading indirect taxes. Income tax thresholds were lowered, leading a much larger proportion of employees to pay income tax. This new system replaced "tax farming", under which provincial governments negotiated a payment to central government and could retain all remaining tax revenues.

The Chinese national government budget (which excludes social security funds) relies predominately on indirect and company taxation for revenue. Within these two groups VAT dominates. It will become even more dominant once the business tax (a sales tax on services) is rolled into the VAT. Moreover these two sets of taxes have tended to grow much faster than national income. Company taxes, though, are more sensitive to cyclical fluctuations than the VAT. By 2011, these three taxes accounted for close to $85 \%$ of all national tax revenue (Figure 1). Individual income tax, which has been in place for three decades, provides limited revenue. The yield from personal income taxation is one-third the yield of corporate tax and $10 \%$ of the yield of indirect taxation. When introduced in 1983, the threshold for payment of income tax was set at 12 times average earnings. In 1999, it was lowered to slightly below average earnings. The threshold was raised at the end of 2011 to $90 \%$ of average earnings.

Figure 1. Sources of tax revenue at the national level

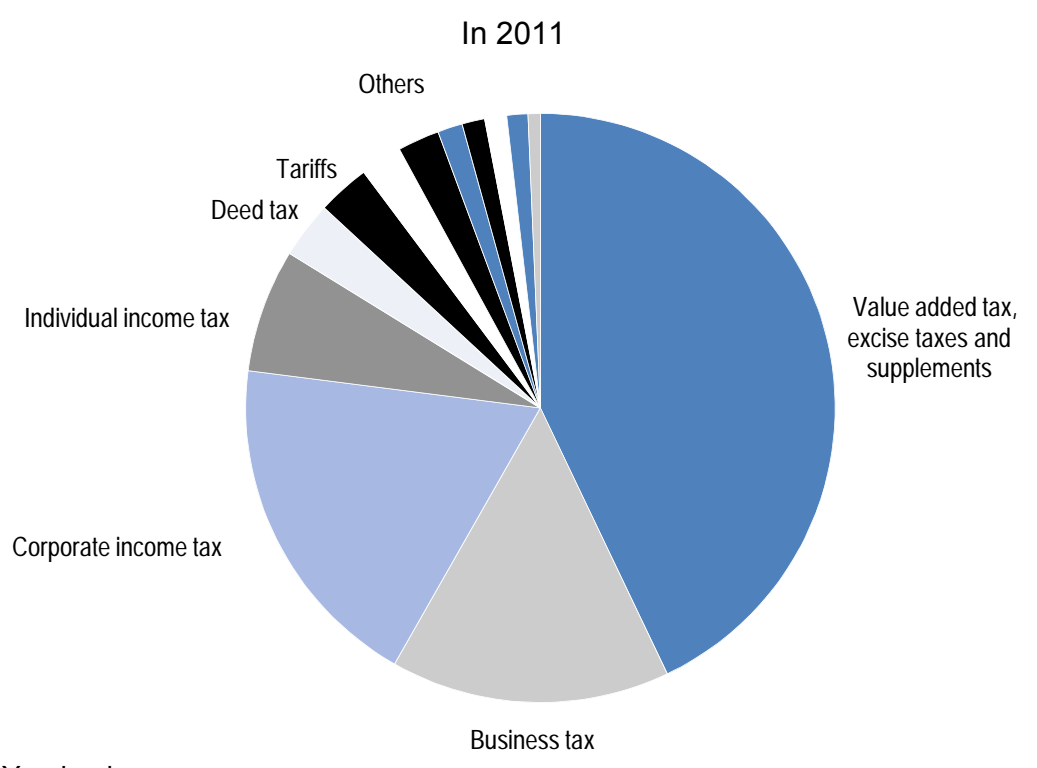

Source: China Statistical Yearbook

\section{Tax assignment}

In China, local governments have no discretionary power to raise taxation, though they can lower taxation by granting tax holidays for new investors. The central government sets the legislation governing taxation and the rate of each tax. Local authorities have no autonomy in the area of taxation in only four OECD countries (Figure 2). In China the central government assigns various portions of taxes directly to local governments. The precise share varies from tax to tax. Just under half of tax revenues are assigned exclusively to either the central or the local governments: pure central government taxes relate to foreign trade or excise taxes on tobacco, alcohol, petroleum products, cars and jewellery (known collectively as the consumption tax); pure local government taxes cover services and property. The remaining portion of tax revenue is shared between central and local governments and accounts for slightly more than half of total tax revenue. Overall the share accrued to the central government is around $70 \%$ (Table 1). 
ECO/WKP(2013)22

Figure 2. Local taxes under the control of local governments

In 2005

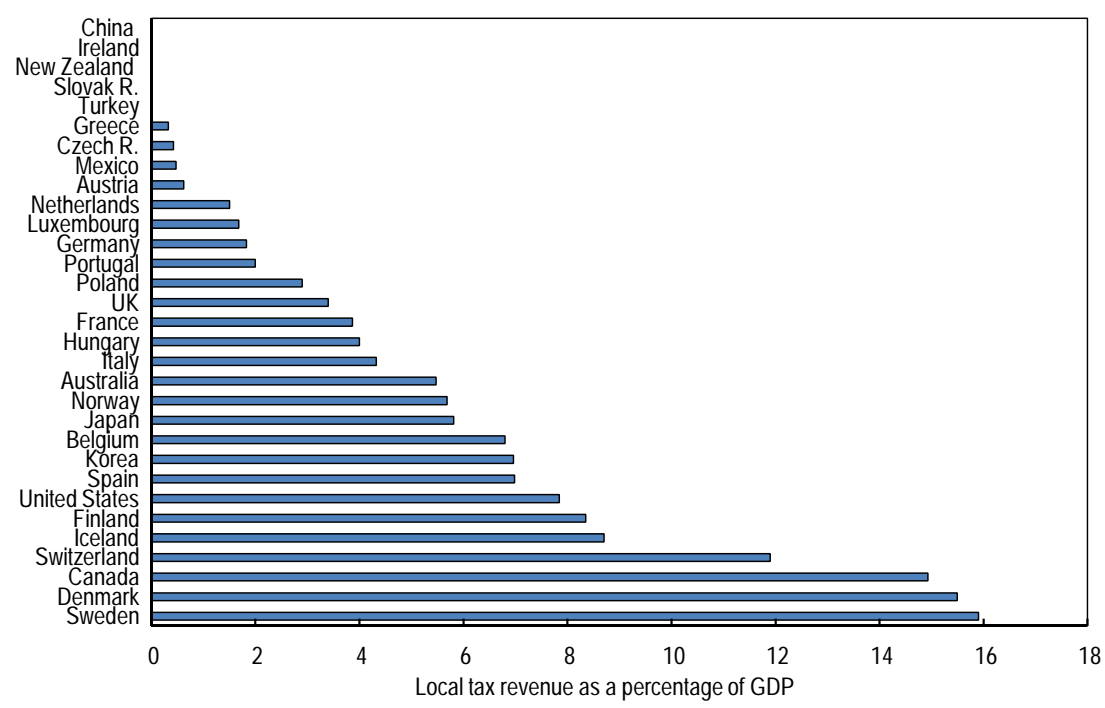

Source: Blöchliger and Rabesona (2009).

Table 1. Revenue assignments and actual revenue for central and local governments

2011

\begin{tabular}{|c|c|c|c|c|c|c|}
\hline & Central & Provincial & Central & Provincial & Central & Provincial \\
\hline & \multicolumn{2}{|c|}{ Legal sharing rate } & \multicolumn{2}{|c|}{ Receipts as \% of } & \multicolumn{2}{|c|}{ CNY billion } \\
\hline Central taxes & & & 32.7 & 0.0 & 1593 & $\mathbf{0}$ \\
\hline Consumption tax & 100 & 0 & 14.3 & 0.0 & 694 & 0 \\
\hline Tariffs & 100 & 0 & 5.3 & 0.0 & 256 & 0 \\
\hline Intl trade-related consumption tax and VAT & 100 & 0 & 27.9 & 0.0 & 1356 & 0 \\
\hline Refunds of VAT and consumption tax on & 100 & 0 & -18.9 & 0.0 & -920 & 0 \\
\hline Vehicle purchase tax & 100 & 0 & 4.2 & 0.0 & 204 & 0 \\
\hline Cargo tax & 100 & 0 & 0.1 & 0.0 & 3 & 0 \\
\hline Shared taxes & & & 66.5 & 36.9 & 3236 & 1517 \\
\hline VAT & 75 & 25 & 37.6 & 14.6 & 1828 & 599 \\
\hline Corporate income tax & 60 & 40 & 20.6 & 16.4 & 1002 & 675 \\
\hline Personal income tax & 60 & 40 & 7.5 & 5.9 & 363 & 242 \\
\hline Stamp tax on securities & 97 & 3 & 0.9 & 0.0 & 43 & 1 \\
\hline Sub-national taxes & & & 0.7 & 63.1 & 34 & 2594 \\
\hline Business tax & 1 & 99 & 0.4 & 32.9 & 17 & 1350 \\
\hline Resource tax & 0 & 100 & 0.0 & 1.4 & 0 & 60 \\
\hline Urban maintenance and development tax & 0 & 100 & 0.3 & 6.3 & 17 & 261 \\
\hline House property tax & 0 & 100 & 0.0 & 2.7 & 0 & 110 \\
\hline Real estate tax & 0 & 100 & 0.0 & 3.0 & 0 & 122 \\
\hline Urban land use tax & 0 & 100 & 0.0 & 5.0 & 0 & 206 \\
\hline Land appreciation tax & 0 & 100 & 0.0 & 0.7 & 0 & 30 \\
\hline Tax on vehicles and boat operation & 0 & 100 & 0.0 & 2.6 & 0 & 108 \\
\hline Tax on the use of arable land & 0 & 100 & 0.0 & 1.5 & 0 & 60 \\
\hline Tobacco tax & 0 & 100 & 0.0 & 0.2 & 0 & 9 \\
\hline Tax on deeds & 0 & 100 & 0.0 & 6.7 & 0 & 277 \\
\hline All taxes & 54.2 & 45.8 & 100.0 & 100.0 & 4863 & 4111 \\
\hline
\end{tabular}

Source: Ministry of Finance (2012a), Fiscal Statistical Yearbook of China 2011; NBS (2012), Statistical Yearbook of China 2012. 
The largest tax assigned to provincial governments is that on services, known as the business tax (Figure 3). This tax complements VAT which is only levied on goods. However, its existence is an anomaly as all goods-specific (and hence cascading) taxes were abolished in 1994 and replaced by VAT on goods. The government is committed to merging the business tax with VAT. The first pilot was undertaken in Shanghai in 2011 and was widened in September 2012 to Beijing, Tianjin, Shenzhen and Xiamen, as well as the provinces of Guangdong, Jiangsu, Zhejiang, Anhui, Fujian and Hubei (Brys and Matthews, 2013). In 2013, the business tax will be replaced by VAT in the following economic zones: Bohai, Yangtze River Delta and Yangtze River, Pearl River Delta and the Straits economic zones.

The remaining taxes assigned to local governments are based mostly on the value or quantity of local assets. Taxes on property have been particularly buoyant in the decade to 2011 , rising by a compound growth rate of $33 \%$ to approach $2 \%$ of GDP. In addition, property developers have to pay the business tax of the value of their sales. This tax is estimated to raise a further $0.5 \%$ of GDP in revenue. It is, though, more of tax on goods and services than a tax on property - even if investment goods are usually exempt from such taxes. Since 2011, householders who sell an apartment within two years of purchase have to pay the business tax. Overall, taxes levied on the use of property amount to $0.7 \%$ of GDP while taxes on the sale of property raise around $1.2 \%$ of GDP (excluding the business tax).

Figure 3. The importance of the various taxes assigned to local government

Percentage of total locally assigned tax revenue in 2011

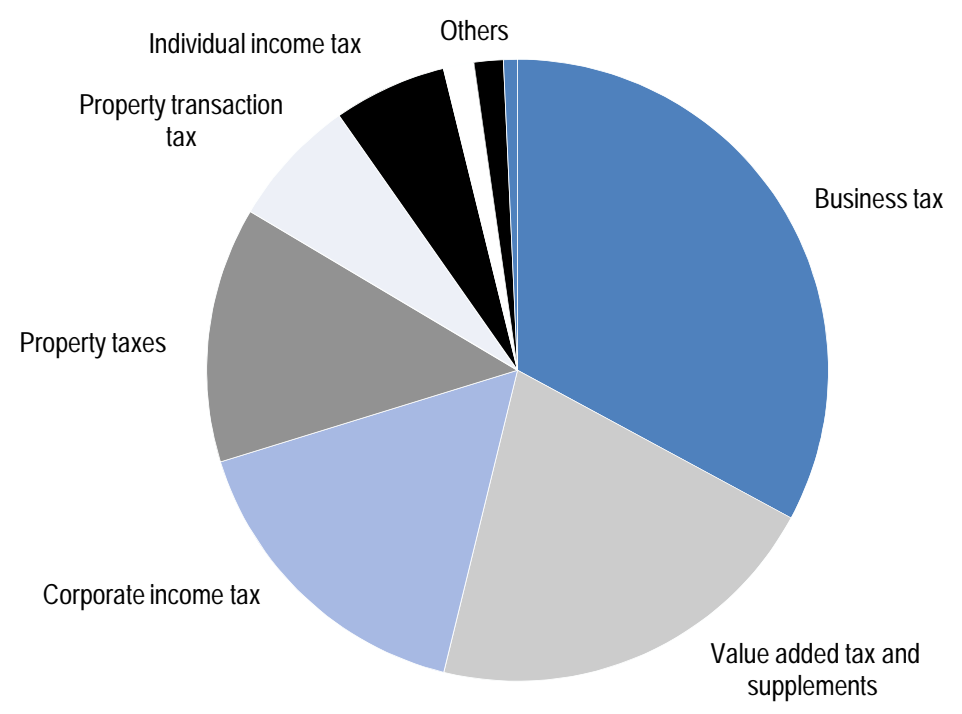

Source: China Statistical Yearbook.

Each level of sub-national government shares their tax income with the levels of government below. Provinces use various mechanisms: $i$ ) the sharing of specific taxes; ii) the assignment of specific taxes; iii) the sharing of the increase in the yield from a base year; and $i v$ ) the assignment of an amount that depends on a predetermined growth rate. On average, the largest share of all local taxes is taken by the prefectural governments (Table 2). This is true of all individual local taxes except the property and resource taxes, which mainly accrue to county and township governments. There are considerable differences both across and within provinces in the distribution of taxes to lower-level authorities. 
ECO/WKP(2013)22

Table 2. Distribution of tax sources by level of sub-national government

In 2009

\begin{tabular}{lcccc|ccc}
\hline & Provincial & Prefecture & County & Township & \multicolumn{2}{c}{ All sub-national governments } \\
\cline { 2 - 7 } & \multicolumn{3}{c}{ \% total tax revenue } & & \multicolumn{2}{c}{ \% GDP } & CNY billion \\
\cline { 2 - 7 } VAT & 19.6 & 32.0 & 31.9 & 16.6 & 100 & 1.3 & 457 \\
Business tax & 29.2 & 30.5 & 29.1 & 11.3 & 100 & 2.6 & 885 \\
Urban maintenance and development tax & 6.4 & 44.5 & 36.1 & 13.0 & 100 & 0.4 & 142 \\
Corporate income tax & 37.8 & 31.1 & 23.0 & 8.1 & 100 & 1.2 & 392 \\
Personal income tax & 34.6 & 31.2 & 25.1 & 9.0 & 100 & 0.5 & 158 \\
Property tax & 8.0 & 37.9 & 39.7 & 14.5 & 100 & 0.1 & 34 \\
Resource tax & 19.4 & 16.7 & 37.0 & 26.9 & 100 & 1.4 & 481 \\
Other & 6.3 & 32.2 & 40.7 & 20.7 & 100 & 0.1 & 49 \\
All local taxes & 23.3 & 32.9 & 31.1 & 12.7 & 100 & 7.6 & 2597 \\
\hline
\end{tabular}

Source: Ministry of Finance (2011b), Local Fiscal Statistical Yearbook, 2009.

\section{Other sources of revenue}

Sub-national governments have non-tax revenue from fees, levies, penalties and the profit from the sale of land-use rights. Overall, non-tax sources of revenue represent slightly under half of their total revenues, amounting to $2.2 \%$ of GDP (Table 3). Sub-national governments have significant income from the ownership of state-owned enterprises, in contrast to the central government. The total amount of nontax income (excluding asset sales) amounts to nearly $30 \%$ of their total revenue.

In the past, fees were major part of non-tax revenue. They were administered through off-budget funds mainly to fund education and transport. Since 2012, all fees have been administered through the budget but reliance on fees remains. Indeed, these fees are one of the three elements of local governments' fiscal autonomy. The other two are income from land sales that accrues to extra-budgetary funds and the financing of infrastructure though infrastructure development companies (which are a reflection of the balanced budget requirements for local authorities that is embedded in the Budget Law).

On top of the non-tax revenue, sub-national governments raise significant amounts from the sale of land-use rights for periods of between 30 and 70 years. These stem from the government's ownership of all urban land and its monopoly of the right to transform land from agricultural to construction use. In 2009, the gross revenue from these sales amounted to some 4.2\% of GDP, rising to over 7\% in 2010 and 2011 , before falling to just over 5\% of GDP in 2012. However, not all of the land sale revenues represent profit for the government, as compensation needs to be paid. In addition the land is sold fully serviced. The cost of installing the road, water, drainage, electricity and telecom networks has to be deducted from the gross sales revenue. In 2009, these two cost elements absorbed half of gross sales revenue. The net revenue from land sales is concentrated on the county and prefecture governments where the profit from land sales is equivalent to some $14 \%$ of their total revenue. By contrast, when the property market was in its infancy in 1999 , net land sales revenues accounted for only $4.5 \%$ of revenue. These governments are constrained as to the use that is made of such revenues: they can only be used to create new physical assets for the government. 
Table 3. Taxes and other sources of revenue by levels of government

In 2009

\begin{tabular}{lcccccc}
\hline & Central & Sub-national & Provincial & Prefecture & County & Township \\
\hline & \multicolumn{7}{c}{$\begin{array}{c}\text { \% of GDP } \\
\text { Taxes }\end{array}$} & 9.8 & 7.6 & 1.8 & 2.5 & 2.4 & 1.0 \\
& & & & & & \\
Fees and penalties & 0.2 & 2.2 & 0.8 & 0.7 & 0.6 & 0.1 \\
Asset income & 0.0 & 0.6 & 0.1 & 0.2 & 0.3 & 0.0 \\
Other & 1.4 & 1.7 & 0.7 & 0.5 & 0.4 & 0.1 \\
Non tax revenue & 1.6 & 4.4 & 1.5 & 1.4 & 1.4 & 0.2 \\
Land sales (net) & 0.0 & 2.1 & 0.1 & 1.1 & 0.9 & 0.0 \\
Non tax plus land sales (net) & 1.6 & 6.5 & 1.7 & 2.5 & 2.2 & 0.2 \\
Total revenue & & & & & & \\
\end{tabular}

Source: Ministry of Finance (2011b), Local Fiscal Statistical Yearbook, 2009.

\section{Expenditure}

The Constitution sets out the extent of the autonomy of sub-national governments and determines the division of functions and powers between the central and local state organs. The division of powers is guided by the principle of giving full scope to the initiative and enthusiasm of the local authorities under the unified leadership of the central authorities.

The people's congresses of provinces, and their respective standing committees, may adopt local regulations. These must not contravene the Constitution, the law or the national administrative rules and regulations. Local congresses must report such local regulations to the Standing Committee of the National People's Congress for the record.

The split of responsibilities is set out in the Constitution. Local governments at and above the county level conduct administrative work concerning the economy, education, science, culture, public health, physical culture, urban and rural development, finance, civil affairs, public security, ethnic affairs, judicial administration and family planning in their respective administrative areas. They also appoint or remove administrative functionaries.

Local governments at and above the county level also direct the work of their subordinate departments and of lower level governments, and have the power to alter or annul inappropriate decisions of their subordinate departments and of lower-level governments. At the same time, they have some autonomy within the limits of their authority and implement the laws and policies of the state in light of the existing local situation. This hierarchical structure limits the extent to which decentralisation leads to policies that differ markedly across the country.

Indeed, a close look at local government expenditure decisions reveals a highly centralised system in which local governments are effectively agents acting on behalf of the central government (OECD, 2006a). The contrast between the nominal decentralisation of responsibilities and the high degree of centralisation of actual authority is further accentuated by the lack of elections or other formal mechanisms for holding local officials accountable to the citizens under their jurisdiction. Moreover, the performance of government officials at lower levels is judged according to criteria set out by higher levels of government. Thus, although comparisons of the share of spending by sub-national governments in total public spending appear to show that China has amongst the most decentralised public sectors in the world, this is misleading. 
Without being autonomous, sub-national bodies make outlays accounting for around four-fifths of all government expenditure (Table 4). The central government only spends one-fifth of total outlays. The county level of government accounts for more than one-third of total spending and has the major share of outlays, followed by the prefecture governments. Moreover, local government finances many public infrastructure investment projects off-budget through local government financing platforms. Adding such quasi-government spending, results in a further increases the share of sub-national spending.

Table 4. Share of each government level by expenditure type

In 2009

\begin{tabular}{|c|c|c|c|c|c|c|c|}
\hline & Central & $\begin{array}{l}\text { All sub- } \\
\text { national }\end{array}$ & Provincial & Prefecture & County & Township & $\%$ total \\
\hline & \multicolumn{7}{|c|}{$\%$ of each expenditure category } \\
\hline Foreign affairs & 97.4 & 2.6 & 1.2 & 0.7 & 0.6 & 0.0 & 0.3 \\
\hline National defence & 97.3 & 2.7 & 0.9 & 1.0 & 0.7 & 0.0 & 4.9 \\
\hline Financial affairs & 91.5 & 8.5 & 3.7 & 3.7 & 1.1 & 0.0 & 1.6 \\
\hline Payments on government bonds & 88.5 & 11.5 & 3.5 & 6.2 & 1.7 & 0.0 & 1.5 \\
\hline Predominately central government & 94.6 & 5.4 & 1.9 & 2.5 & 0.9 & 0.0 & 8.3 \\
\hline Science and technology & 51.5 & 48.5 & 17.7 & 16.0 & 13.7 & 1.0 & 2.8 \\
\hline Reserve for cereals and oils & 34.8 & 65.2 & 28.6 & 12.5 & 22.4 & 1.7 & 6.6 \\
\hline Transportation & 28.9 & 71.1 & 42.9 & 15.2 & 12.7 & 0.4 & 2.2 \\
\hline Affordable housing & 25.7 & 74.3 & 24.3 & 40.5 & 9.4 & 0.1 & 0.1 \\
\hline Mixed central and provincial & 35.4 & 64.6 & 34.0 & 15.1 & 14.7 & 0.8 & 11.8 \\
\hline Mining, quarrying, electricity and IT & 22.2 & 77.8 & 17.5 & 32.6 & 23.9 & 3.9 & 4.8 \\
\hline Public security & 17.4 & 82.6 & 18.5 & 28.9 & 34.1 & 1.0 & 2.2 \\
\hline Culture, sport and media & 16.7 & 83.3 & 27.4 & 28.4 & 25.4 & 2.1 & 3.6 \\
\hline Other expenditure & 19.3 & 80.7 & 23.1 & 27.0 & 26.5 & 4.1 & 3.6 \\
\hline Mainly prefecture and province & 19.0 & 81.0 & 20.8 & 29.3 & 28.3 & 2.7 & 14.2 \\
\hline Urban and rural community affairs & 1.1 & 98.9 & 5.6 & 46.8 & 42.2 & 4.3 & 9.7 \\
\hline Social safety net and employment & 5.4 & 94.6 & 20.5 & 27.4 & 42.0 & 4.7 & 12.9 \\
\hline General public services & 11.3 & 88.7 & 18.3 & 21.4 & 36.1 & 12.8 & 8.5 \\
\hline Environment protection & 1.9 & 98.1 & 21.5 & 26.6 & 46.9 & 3.0 & 4.2 \\
\hline Agriculture and water conservancy & 6.5 & 93.5 & 24.3 & 14.8 & 45.3 & 9.0 & 2.0 \\
\hline Education & 6.7 & 93.3 & 18.4 & 19.3 & 50.3 & 5.4 & 19.4 \\
\hline Post-earthquake recovery & 10.4 & 89.6 & 21.6 & 10.6 & 53.1 & 4.3 & 7.7 \\
\hline Medical and healthcare & 1.5 & 98.5 & 14.8 & 25.4 & 55.9 & 2.5 & 1.3 \\
\hline Mainly county/district/township & 5.1 & 94.9 & 15.5 & 28.7 & 44.5 & 6.2 & 65.7 \\
\hline All types of expenditure & 18.1 & 81.9 & 17.3 & 25.0 & 35.1 & 4.6 & 100 \\
\hline
\end{tabular}

Source: Ministry of Finance (2011b), Local Fiscal Statistical Yearbook 2009.

Although they account for only one-fifth of total sub-national public spending, provincial governments are active in most types of outlays (Table 5). A large part of provincial expenditure is focussed on economic affairs (such outlays on various industries, science and technology and transportation) which require a strategic focus (Kamal-Chaoui et al., 2009). Nonetheless, provincial governments allocate almost $60 \%$ of their spending to outlays that are mainly undertaken by lower levels of government (education, health and the social safety net). Social security spending is also decentralised. These types of expenditure assignments are generally central government functions, as social security programmes generally entail risk pooling and redistribution in order to guard against economic shocks that only affect one area and to ensure that poor neighbourhoods are not overburdened by social payments (OECD, 2010). 
Table 5. Public expenditure by level of government

In 2009

\begin{tabular}{|c|c|c|c|c|c|c|c|}
\hline & Central & All sub-national & Provincial & Prefecture & County & Township & $\%$ total \\
\hline & \multicolumn{7}{|c|}{$\%$ of each expenditure by each government level } \\
\hline Foreign affairs & 1.4 & 0.0 & 0.0 & 0.0 & 0.0 & 0.0 & 0.3 \\
\hline National defense & 26.6 & 0.2 & 0.3 & 0.2 & 0.1 & 0.0 & 4.9 \\
\hline Financial affairs & 8.1 & 0.2 & 0.3 & 0.2 & 0.0 & 0.0 & 1.6 \\
\hline Payments on government bonds & 7.3 & 0.2 & 0.3 & 0.4 & 0.1 & 0.0 & 1.5 \\
\hline Predominantly central government & 43.4 & 0.5 & 0.9 & 0.8 & 0.2 & 0.0 & 8.3 \\
\hline Science and technology & 8.0 & 1.7 & 2.9 & 1.8 & 1.1 & 0.6 & 2.8 \\
\hline Reserve for cereals and oils & 10.6 & 5.8 & 16.4 & 4.0 & 2.4 & 0.5 & 6.6 \\
\hline Transportation & 4.3 & 1.8 & 3.7 & 1.1 & 1.4 & 0.8 & 2.2 \\
\hline Affordable housing & 0.1 & 0.1 & 0.1 & 0.2 & 0.0 & 0.0 & 0.1 \\
\hline Mixed central and provincial & 23.1 & 9.3 & 23.2 & 7.1 & 5.0 & 2.0 & 11.8 \\
\hline Mining, quarrying, electricity and IT & 4.7 & 4.9 & 5.2 & 5.6 & 4.7 & 1.1 & 4.8 \\
\hline Public security & 2.0 & 2.3 & 3.5 & 2.5 & 1.6 & 1.0 & 2.2 \\
\hline Culture, sport and media & 4.4 & 3.4 & 3.6 & 4.6 & 2.4 & 3.0 & 3.6 \\
\hline Other expenditure & 3.8 & 3.5 & 4.8 & 3.9 & 2.7 & 3.2 & 3.6 \\
\hline Prefecture and province & 14.9 & 14.1 & 17.1 & 16.6 & 11.5 & 8.4 & 14.2 \\
\hline Urban and rural community affairs & 6.1 & 10.5 & 10.2 & 8.3 & 10.0 & 27.2 & 9.7 \\
\hline Social safety net and employment effort & 4.8 & 14.7 & 13.7 & 9.9 & 18.5 & 15.2 & 12.9 \\
\hline General public services & 2.6 & 9.8 & 10.1 & 9.3 & 10.2 & 8.8 & 8.5 \\
\hline Environment protection & 0.4 & 5.1 & 3.6 & 4.3 & 6.8 & 2.3 & 4.2 \\
\hline Agriculture and water conservancy & 0.2 & 2.4 & 2.5 & 2.1 & 2.7 & 1.3 & 2.0 \\
\hline Education & 1.1 & 23.5 & 6.3 & 36.4 & 23.4 & 18.4 & 19.4 \\
\hline Post-earthquake recovery & 2.8 & 8.8 & 10.8 & 4.5 & 9.9 & 15.2 & 7.7 \\
\hline medical and healthcare & 0.7 & 1.4 & 1.6 & 0.5 & 1.9 & 1.2 & 1.3 \\
\hline County/district/township & 18.6 & 76.1 & 58.8 & 75.4 & 83.4 & 89.6 & 65.7 \\
\hline All types of expenditure & 100 & 100 & 100 & 100 & 100 & 100 & \\
\hline
\end{tabular}

Source: Ministry of Finance (2011b), Local Fiscal Statistical Yearbook 2009.

Over the past decade, the share of spending undertaken by local authorities has increased markedly (Figure 4). This reflected a major change in the orientation of public spending towards spending on public services rather than economic services - in line with the conclusions of an OECD report on Chinese public finances (OECD, 2006a). This re-orientation followed a seven-year period when the government restored spending after its collapse during the first half of the 1990s. The increase in sub-national public spending was particularly pronounced at the prefectural and county levels as these are the levels of government that deliver services to people.

Higher-level government has the power to determine the expenditure responsibilities of the level immediately below it: provinces determine the assignments of prefectures, prefectures the assignments of districts, counties and county cities, and the latter two the assignments of townships (Shen et al., 2012). Consequently some have argued that higher-level governments have been increasingly devolving assignments to lower local levels of government (Kamal-Chaoui et al., 2009; Li et al., 2010). The devolved categories include not only pre-determined sub-national responsibilities, such as urban maintenance and construction, but also the incremental part of service provision for education and healthcare spending. In reality, though, this downward movement of expenditure reflected a change in spending priorities towards those services provided at the sub-national level (especially at the county level) that was approved in budgets by the National People's Congress. 
Figure 4. Central and local government expenditure as share of GDP

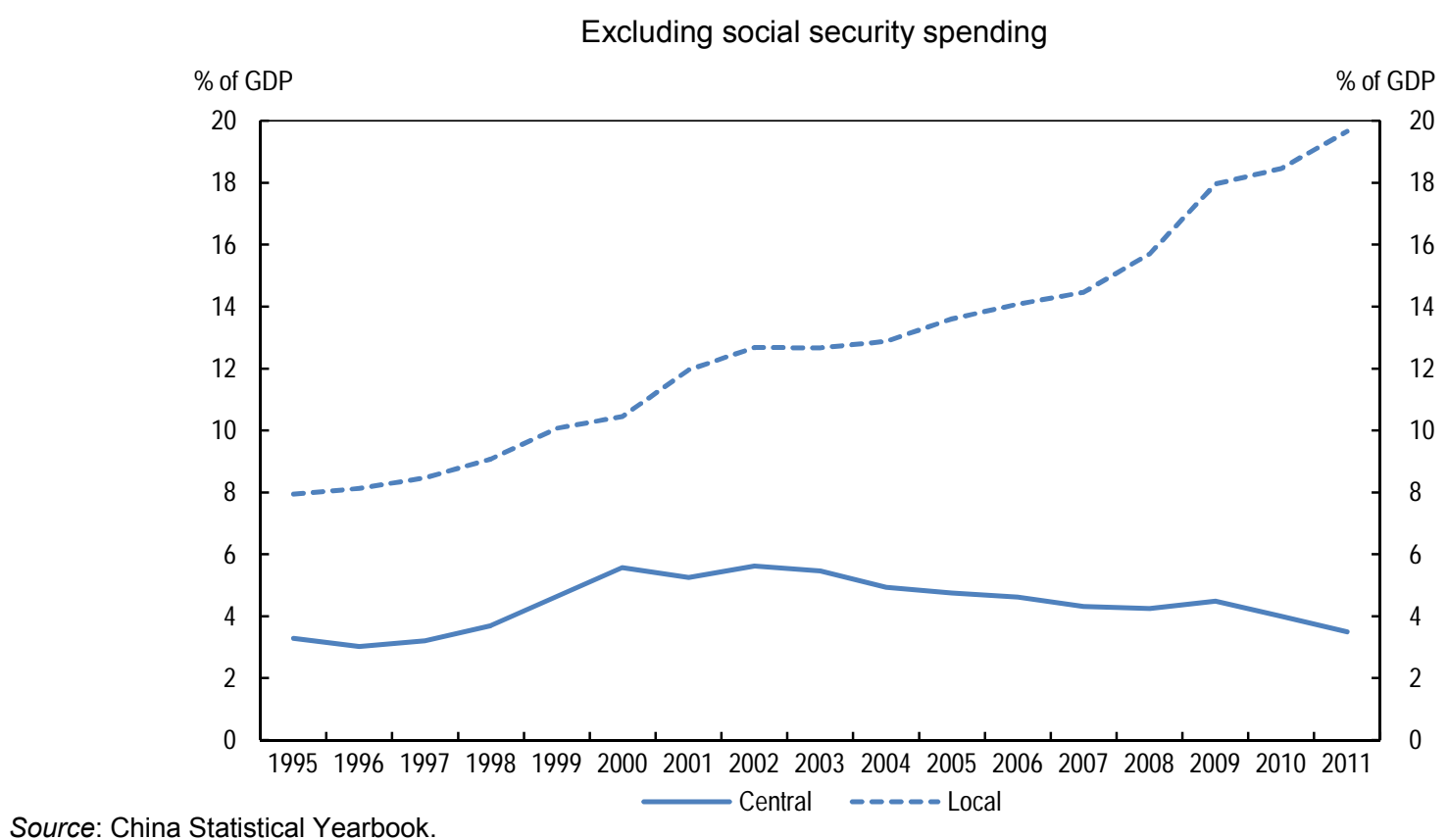

Source: China Statistical Yearbook.

\section{Vertical balance between expenditure and revenue}

The gaps between fiscal resources (tax and non-tax, but excluding transfers) and expenditure depend on the position of the authority in the vertical hierarchy of government (Table 6). For sub-national government as a whole, expenditure has grown much faster than fiscal resources. The gap between fiscal resources and expenditure is particularly marked for rural counties, where fiscal revenue amounts to only slightly more than one quarter of their expenditure. The gap is much lower for the more urban county cities and falls yet again in the urban districts of prefectural level cities.

Table 6. Balance between expenditure and the sum of tax and non-tax revenues

In 2009

\begin{tabular}{lcc|ccc}
\hline & \multicolumn{2}{c|}{ Revenue } & Expenditure & \multicolumn{3}{c}{ Balance } \\
\cline { 2 - 6 } & \multicolumn{2}{c}{ CNY billion } & CNY billion & \% of revenues & \% of national GDP \\
\cline { 2 - 6 } Central & 3878 & 1814 & 2064 & 53 & 6.1 \\
Sub-national & 5543 & 8220 & -2677 & -48 & -7.9 \\
& & & & & -1.5 \\
Provincial & 1220 & 1736 & -516 & -42 & -1.3 \\
Prefecture & 2063 & 2510 & -447 & -22 & -1.0 \\
District & 957 & 1291 & -334 & -35 & -1.0 \\
County city & 383 & 710 & -327 & -85 & -3.2 \\
County & 403 & 1498 & -1094 & -271 & -0.1 \\
Township & 410 & 458 & -47.2 & -11 & 2009 Fisca Sta \\
\hline
\end{tabular}

Source: Ministry of Finance (2011b), Local Fiscal Statistical Yearbook, 2009. Ministry of Finance (2011a), 2009 Fiscal Statistics of Prefectures, Cities and Counties. 


\section{Horizontal balance between regions}

Economic and fiscal inequality between regions is much higher in China than in most OECD countries (Table 7). The tax sharing arrangements do not incorporate any redistributive formula and so the inequality of tax revenue per capita is very similar to the inequality of GDP per capita. Indeed, in China there is no correlation between the average tax rate for each province and its level of development. There is considerable variation in the average tax rate due to factors linked to the structure of the economy of each province. An analysis of variance suggests that around $80 \%$ of the variation in tax revenues per capita is due the variation of per capita GDP, rather than tax rates.

Table 7. Regional inequality in China and selected OECD countries

\begin{tabular}{|c|c|c|c|c|c|}
\hline & \multirow{3}{*}{$\begin{array}{c}\begin{array}{c}\text { Economic } \\
\text { imbalances }\end{array} \\
\text { GDP per capita } \\
\text { Gini coefficient }\end{array}$} & \multicolumn{4}{|c|}{ Fiscal imbalances before equalisation (in percent) } \\
\hline & & \multicolumn{4}{|c|}{ Local tax per capita relative to average tax per capita } \\
\hline & & Gini coefficient & Highest region & Lowest region & $\begin{array}{l}\text { Ratio of highest to } \\
\text { lowest region }\end{array}$ \\
\hline Austria & 0.15 & 0.02 & 107 & 93 & 1.2 \\
\hline Australia & 0.11 & 0.05 & 104 & 80 & 1.3 \\
\hline Germany & 0.12 & 0.06 & 117 & 67 & 1.8 \\
\hline Sweden & 0.06 & 0.06 & 118 & 84 & 1.4 \\
\hline Denmark & 0.13 & 0.08 & 134 & 62 & 2.2 \\
\hline Canada & 0.17 & 0.10 & 177 & 75 & 2.4 \\
\hline Finland & 0.10 & 0.11 & 143 & 79 & 1.8 \\
\hline Norway & 0.11 & 0.13 & 142 & 64 & 2.2 \\
\hline Spain & 0.11 & 0.15 & 142 & 67 & 2.1 \\
\hline Switzerland & n.a. & 0.15 & 173 & 46 & 3.8 \\
\hline Japan & 0.09 & 0.20 & 183 & 58 & 3.2 \\
\hline Italy & 0.14 & 0.21 & 146 & 24 & 6.1 \\
\hline Turkey & 0.25 & 0.22 & 130 & 2 & 65.0 \\
\hline Portugal & 0.15 & 0.34 & 331 & 26 & 12.7 \\
\hline \multicolumn{6}{|c|}{ Average of above countries } \\
\hline Unweighted & 0.13 & 0.13 & 153 & 59 & 2.6 \\
\hline Weighted & 0.14 & 0.16 & 152 & 51 & 3.0 \\
\hline China (2010) & 0.33 & 0.31 & 370 & 36 & 10.3 \\
\hline China (2000) & 0.36 & 0.33 & 503 & 35 & 14.4 \\
\hline
\end{tabular}

Note: For federal/regional countries the indicators are calculated for the state/regional level and include every single jurisdiction. For unitary countries, local governments are grouped into deciles (or "tenths") ranked in increasing order of fiscal capacity before equalisation. Both sections of the table show the Gini coefficients of per capita tax revenue across sub-central governments, and the maximum and minimum fiscal capacity before and after receiving transfers. Year 2004 figures are used for OECD countries, except Germany (2005). For China, the Gini coefficient is calculated based on prefectural level fiscal data, weighted by population size.

Source: Blöchliger and Charbit, 2008; Ministry of Finance (2012a), Fiscal Statistical Yearbook of China 2011 and 2001; OECD Regional statistics.

The way in which the economic structure of a province interacts with the tax assignments is one reason for the variation in tax rates. For corporate taxes, when companies operate across several provinces, it is extremely difficult to allocate profit between provinces. An allocation using value added, employment or assets would transform the tax into a tax on the factor used as a key for allocation rather than a tax on profits. Consequently, the entire profit of a company is allocated to the province where the company has its headquarters. As a result Beijing and Shanghai have particularly high revenues from this source. Equally, the tax sharing agreement allocates all taxes on services to provinces. However, service activities are not distributed equally across the nation and here Beijing and Shanghai benefit again. Hainan though gains 
from its large tourist industry (Figure 5). On the other hand, for value-added tax and other local taxes, there is much less variation across provinces (Table 8).

Figure 5. Overall revenues by type and province

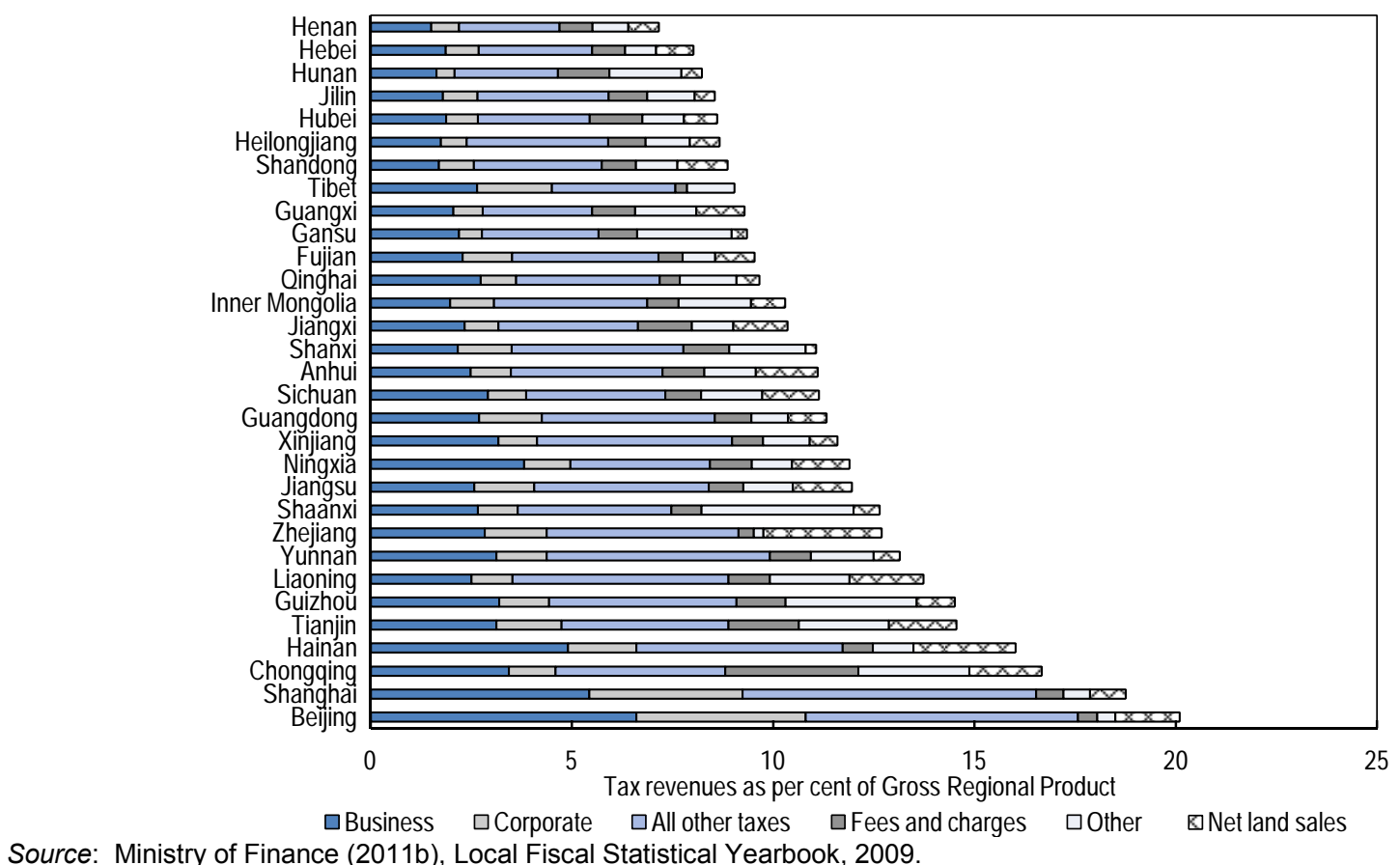

Table 8. Dispersion of different tax and non-tax revenues across provinces

In 2009

\begin{tabular}{|c|c|c|c|c|c|c|c|}
\hline & $\begin{array}{l}\text { Taxes except } \\
\text { business and } \\
\text { corporate tax }\end{array}$ & $\begin{array}{l}\text { Business } \\
\quad \text { tax }\end{array}$ & $\begin{array}{l}\text { Corporate } \\
\quad \text { tax }\end{array}$ & $\begin{array}{l}\text { Fees } \\
\text { and } \\
\text { charges }\end{array}$ & $\begin{array}{l}\text { Other non- } \\
\quad \text { tax } \\
\text { revenue }\end{array}$ & $\begin{array}{l}\text { Total } \\
\text { revenue }\end{array}$ & $\begin{array}{l}\text { Net } \\
\text { land } \\
\text { sales }\end{array}$ \\
\hline & \multicolumn{7}{|c|}{$\%$ of Gross Regional Product } \\
\hline \multicolumn{8}{|l|}{$\begin{array}{l}29 \text { provinces } \\
\text { and municipalities }\end{array}$} \\
\hline Mean & 3.8 & 2.5 & 1.1 & 1.0 & 1.5 & 9.9 & 1.1 \\
\hline Standard deviation & 0.8 & 0.7 & 0.4 & 0.5 & 0.8 & 2.1 & 0.6 \\
\hline Coefficient of variation & 0.22 & 0.29 & 0.33 & 0.53 & 0.51 & 0.22 & 0.56 \\
\hline \multicolumn{8}{|l|}{ Beijing and Shanghai } \\
\hline Mean & 7.0 & 6.0 & 4.0 & 0.6 & 0.6 & 18.2 & 1.2 \\
\hline
\end{tabular}

Source: Ministry of Finance (2011b), Local Fiscal Statistical Yearbook, 2009.

\section{Fiscal disparities within provinces}

Fiscal disparities are starker within than across provinces. Horizontal fiscal disparity measured by Gini coefficient at the sub-provincial level is 0.53 , well above the provincial level figure of 0.31 (Tables 7 and 9). The Theil index shows that $75 \%$ of the overall national disparity can be attributed to withinprovince factors. In particular, fiscal disparity among counties or county cities is substantially higher than across prefecture-level cities (PLCs) and urban districts. The levels of the inequality indices suggest that the principal problem of differences in tax revenue per capita occur in county areas. This inequality is related to the very different economic experience of counties across a province. As shown in Herd et al. (forthcoming), there are many counties and county cities that are, in reality as urban as urban districts according to the metrics of either population density or gross local product per capita. 
Table 9. Revenue imbalances at different levels of government

\begin{tabular}{lc|c|c|} 
& \multicolumn{3}{c}{ In 2009} \\
& \multicolumn{1}{c}{$\begin{array}{c}\text { All sub-provincial } \\
\text { units }\end{array}$} & $\begin{array}{c}\text { Prefecture-level cities } \\
\text { and districts }\end{array}$ & $\begin{array}{c}\text { Counties and } \\
\text { county-level cities }\end{array}$ \\
\cline { 2 - 4 } & \multicolumn{3}{|c|}{ Inequality index } \\
Theil & 0.12 & 0.08 & 0.13 \\
Between-province & 0.39 & 0.14 & 0.33 \\
Within-province & 0.51 & 0.22 & 0.47 \\
Country-wide & 0.53 & 0.37 & 0.50 \\
Gini & \multicolumn{3}{c}{. }
\end{tabular}

Note: The Theil index provides a way to measure the discrepancy between the structure of the distribution of income (or another variable) across groups and the structure of the distribution of individuals across those same groups. The Theil inequality index summarises the distribution of a variable by calculating sum of the logarithms of the quotient of value for a group and the average for all groups weighted by the share of the group. For example, when all population groups have the same income share as their population share then the Theil index is zero. In this case, the calculation assumes that prefectures spend all their revenue in their urban districts rather than in counties.

Source: OECD calculations and Ministry of Finance (2011a), 2009 Fiscal Statistics of Prefectures, Cities and Counties.

Within-province disparities in expenditure are also large, signalling limited service provision capacity in some counties. Overall, the richest sub-provincial unit spends about 29 times as much per capita as the poorest unit. The ratios between extremes are 13 times within PLCs, 15 times within county cities, and 26 times within counties (Ministry of Finance, 2011a). In particular, unlike PLCs and county cities, counties with limited fiscal resources have less leeway to provide matching funds for additional spending mandates requested from superior authorities. This could result in substandard service delivery, for instance in renovating school facilities in poor rural areas (Shen et al., 2012).

\section{Inter-governmental transfers}

\section{Tax sharing}

In China, almost half of national tax revenue is allocated to local governments through tax-sharing agreements. Tax sharing can take several forms. Following Blöchliger and Petzold (2010), strict tax sharing between government levels implies meeting four criteria simultaneously:

- Individual proportionality: The revenue share of each sub-central government is strictly related to tax revenue generated on its own territory.

- Risk sharing: the amount of revenue allocated to the sub-central level is strictly related to the total tax intake.

- Un-conditionality: The sub-central government is free to use the allocated revenue.

- Formula stability: The revenue share between the central and the sub-central government is predetermined in advance and not changed during the period of the agreement.

China is unusual in that its tax-sharing system follows the strict model outlined above, in contrast to nearly all OECD countries (Figure 6). Despite having no authority to borrow, sub-national governments are fully exposed to the risk of fluctuations in tax revenues from either a factor specific to one province or general business cycle fluctuations. The exposure to volatility is particular large for their share of corporate income tax. They are also free to allocate the cash in line with their spending priorities subject to the overall priorities set by the National People's Congress. There is individual proportionality in allocating taxes, which encourages local governments to boost economic activity in their jurisdiction. 
Figure 6. Strict tax sharing and other forms of sub-national government revenue

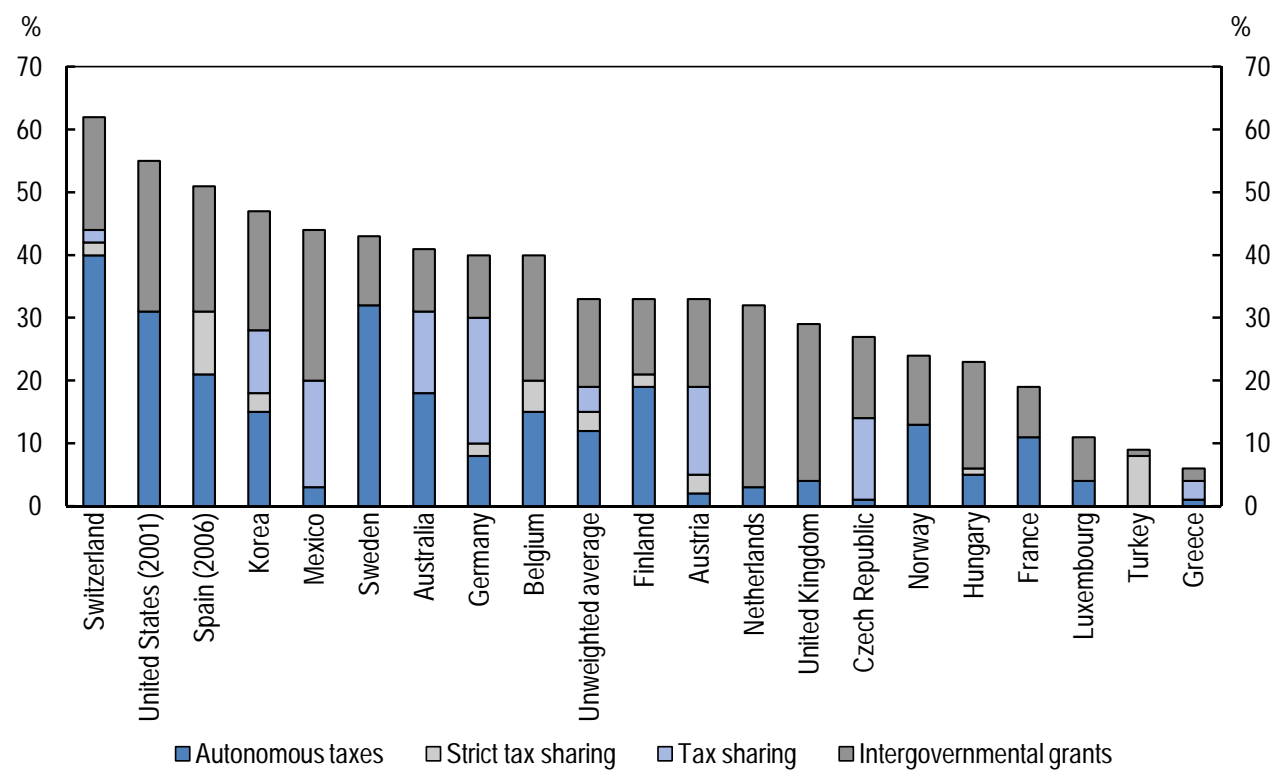

Source: Blöchliger and Petzold (2010).

There is a well-defined formula for allocating different taxes, which has been slightly changed three times since 1994. It has not been altered since 2003, when the central share in income taxes was raised from 50 to $60 \%$, the share of stamp duty on financial transactions rose from 50 to $97 \%$, and the business tax on the financial industry was assigned to the central government. Since the 1990s, the proportion of total expenditure undertaken by sub-national government has risen considerably. The discrepancy between a fixed revenue share and rising expenditure share has driven much of the growth in vertical fiscal inequalities: by the time the system devised in 1994 was fully operational in 1999, the aggregate tax share of sub-national government was $46 \%$ while their expenditure share was $69 \%$; and by 2011 , the tax share had remained constant at $46 \%$ of total tax revenues, while the expenditure share had risen to $85 \%$. A mechanical calculation suggests that if the average tax share were raised to $62 \%$, the gap between expenditure and revenue would be lowered to the level observed in 1999. This would eliminate the gap between revenue and expenditure for the aggregate of provincial, prefecture, urban districts and county cities. The remaining fiscal gaps would be found almost exclusively at county level and would presumably be concentrated in the poorest counties.

\section{Transfers}

One of the stated objectives of the 1994 tax reform was to recentralise decision-making and enable the central government to better control policy implementation across the country. In order to accommodate a strong increase in the share of expenditure in the areas covered by sub-national government not matched by increased tax revenues, the government designed a new transfer system, which has three components:

- General transfers used to lower disparities in expenditure.

- Earmarked transfers used to subsidise local projects in certain areas subject to matching outlays by local government.

- Compensation transfers designed to reduce the revenue loss accruing to some local governments after the 1994 tax reform. 
Each of the three groups has a number of sub-components (Figure 7). Some of the grants under the general transfer component resemble earmarked grants. However, they do not require matching funds. Moreover they accrue to provinces according to their GDP per capita. The wage adjustment grant varies by a factor of four between eastern and western provinces. The compulsory education grant is only paid to rural counties and compensated for the abolition of the agricultural tax, previously used to fund education.

Figure 7. Major components of central-provincial transfers

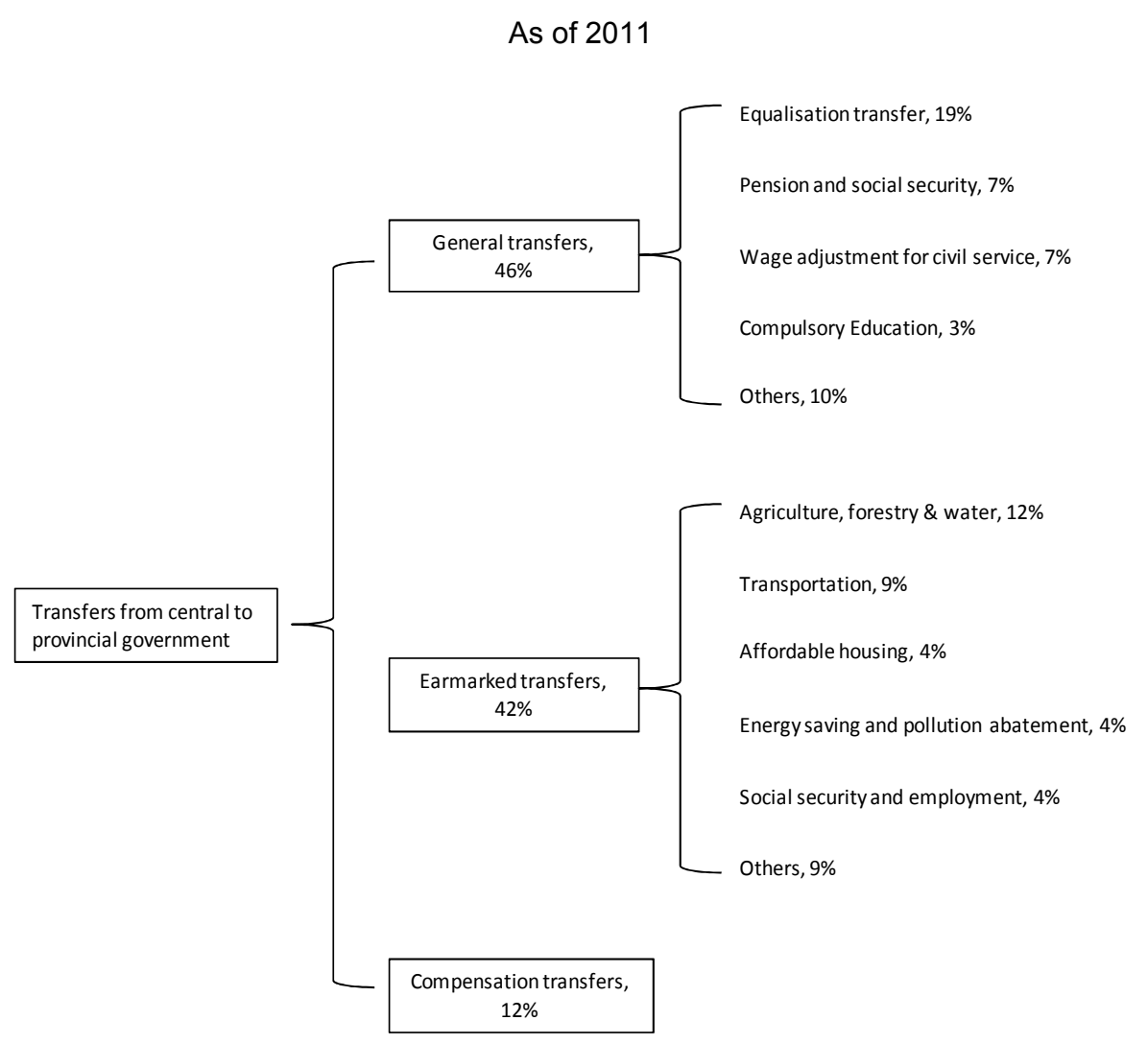

Source: Ministry of Finance, Finance Yearbook 2012.

Immediately after the 1994 tax reform, the predominant form of transfer was that which compensated regions that had lost as a result of the tax reform. The formula was designed to ensure that the grant component fell gradually relative to GDP. As local tax receipts failed to keep up with expenditure, the share of general and earmarked transfers rose (Figure 8). By 2011, these forms of transfer dominated. There are some 20 categories of over 100 different recurrent transfers classified as earmarked transfers while there are 18 types of relatively fixed types of grants defined as general transfers. The main form of general transfer is the equalisation transfer, accounting for $19 \%$ of total transfers in 2011. It aims to lower spending inequality across the country (Box 2). 
Figure 8. Different types of transfers as a share of national tax revenues

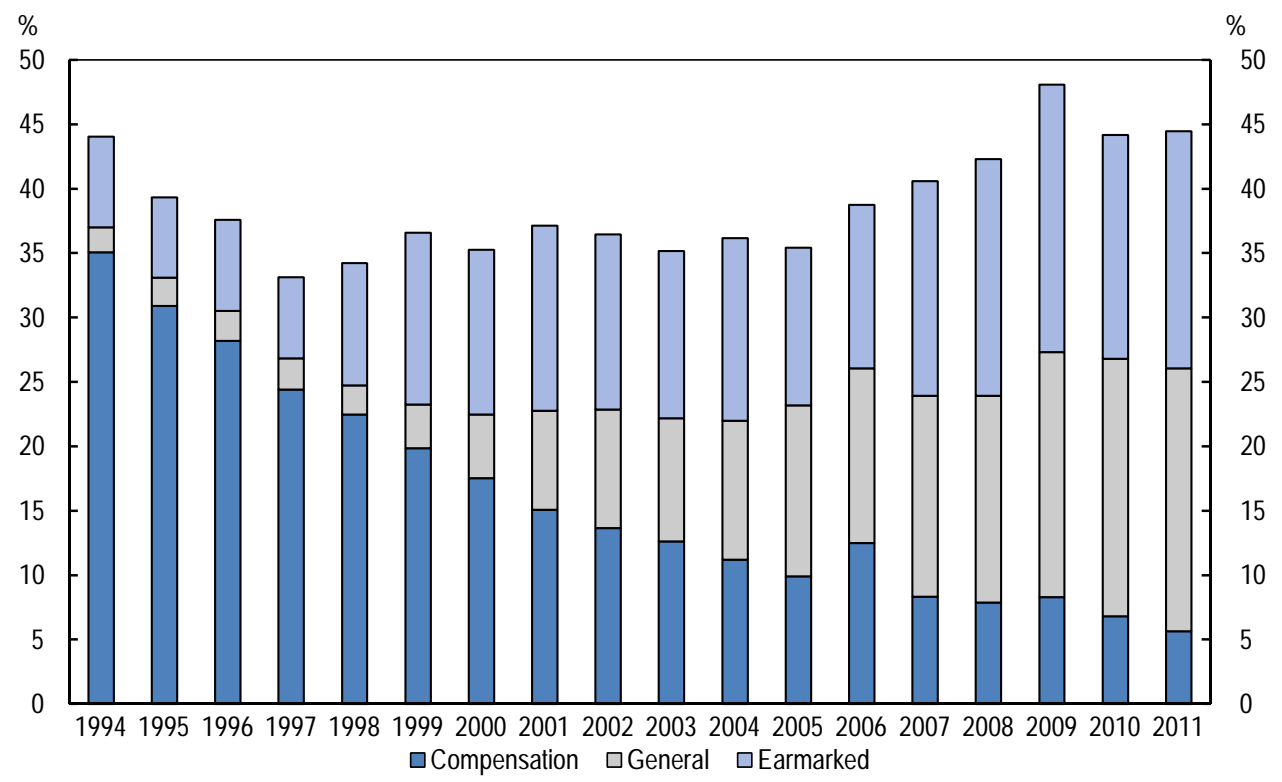

Source: Ministry of Finance, Finance Yearbook 2012.

\section{Box 2. The design of the equalisation transfer}

The formula used to calculate this transfer is based on the gap between standard revenue capacity and standard current expenditures. The former is estimated using the tax bases and standard tax rates, while the latter are calculated based on different per capital spending for different categories of outlays for adjusted cost factors such as altitude, population density, temperature, transport distance and the proportion of the population belonging to minority groups. The categories of spending include administration services, public safety, education, urban maintenance, healthcare, environmental protection and social assistance.

The transfer amount is also adjusted for coefficients that take into account the size of the standard gap, the actual gap, and the total amount allocated from central government revenue. Moreover, rewards in terms of additional grants are given to provinces that achieve better fiscal equalisation results at sub-provincial levels (top five performers).

Algebraically, the amount of the equalisation transfer for a province is given by:

$$
E T_{i}=T E T \frac{S E_{i}-S R_{i}}{S E-S R} \sigma_{i}+\Delta_{\mathrm{i}}+R E_{i}
$$

where:

$E T i=$ the equalisation transfer for province $i$

$T E T=$ total equalisation grant available in the budget year. The size is determined by the increase in the shared income tax allotted to the central government, plus an extra amount allocated on an ad-hoc basis, subject to annual funding availability. 
$S E i=$ standard expenditure of province $i$. It is the sum of total standardised spending for 14 sectors. For each sector, the standard national average standard expenditure per registered inhabitant is calculated. The national average is then converted to a provincial average by adjusting for cost differences caused by the difference from the national average of altitude, population density, temperature, transport distances, the number of civil servants, regional wage differentials, number of students and the prevalence of minority groups. The cost factors vary according to the spending category. Total standardised spending was calculated as the product of standardised spending per registered inhabitant and the number of registered inhabitants (irrespective of where they actually live) during the period 1995 to 2011 . Since 2012, the population measure used is the registered population plus $15 \%$ of the difference between the actual population and the registered population.

$S R i=$ standard revenue of province $\mathrm{i}$. For each type of tax, standard tax revenue is determined by multiplying the standard tax base with the standard tax rate.

$S E=$ total standard expenditure of the country.

$S R=$ total standard revenue of the country.

$\sigma_{i}=$ fiscal difficulty index of province $i$, calculated as the sum of spending on wages for civil servants, operating expenses and payments for the basic livelihood allowance as a percentage to standard revenue.

$\Delta_{i}=$ adjustment index of province $i$ based on the difference between the change in the actual grant and the baseline predicted amount.

$R E_{i}=$ reward grant allotted to province $i$, if any (only to top five performers of fiscal equalisation results at subprovincial levels).

Originally only 18 provinces were eligible for equalisation transfers. This was widened to 25 in 2002 and has remained constant since. Six provinces remain ineligible for such transfer: Beijing, Guangdong, Jiangsu, Shanghai, Tianjin and Zhejiang.

\section{The grant system favours poorer areas}

The strong weight given to the transfers designed to help poorer areas has successfully boosted incomes in these areas. One metric to assess the success is the extent to which transfers to different areas when measured relative to that area's GDP fall as GDP per capita increases. Across provinces, this is indeed the case (Figure 9). Broadly speaking a 10\% decline in relative income (from $50 \%$ to $45 \%$ of average income) is associated with an increase of transfers of 1.2 percentage points of GDP. Other factors are also important in determining the extent of the transfer. 
Figure 9. Transfers to provinces and the level of development

2009, Percentage of regional GDP, excluding Qinghai and Tibet

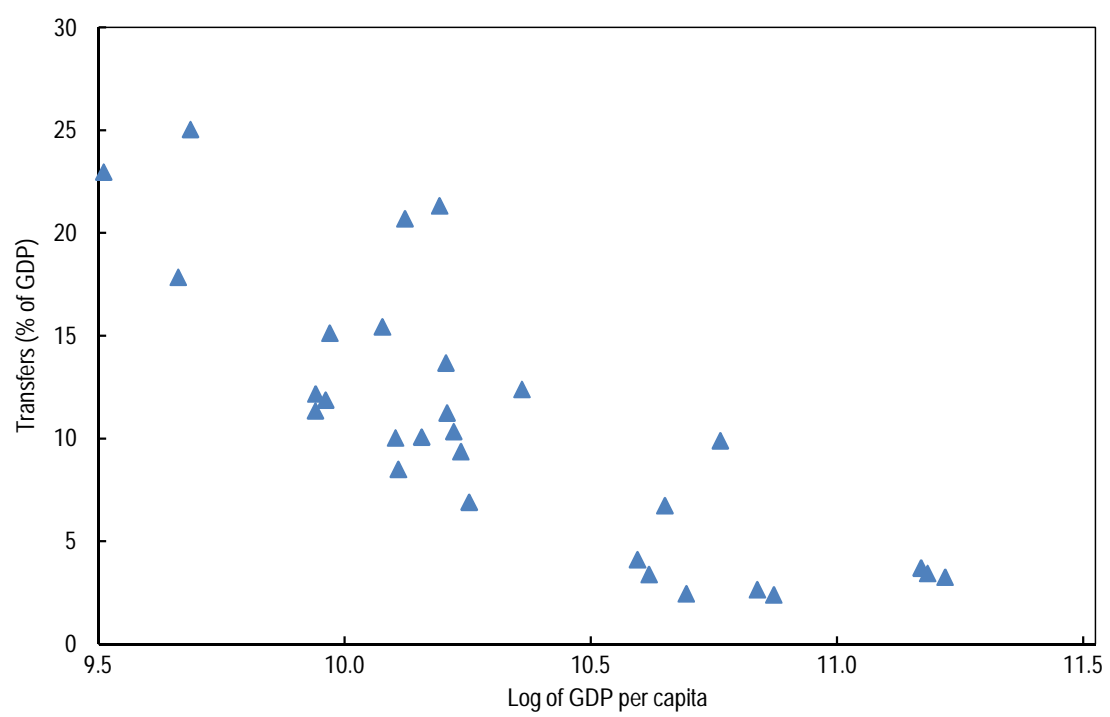

Source: OECD calculations and Ministry of Finance (2011a), 2009 Fiscal Statistics of Prefectures, Cities and Counties

The increasing importance of transfers for poorer areas is seen not just at the province level but also at the county level. The bulk of counties receive transfers of less than $50 \%$ of their local GDP. Over the range of transfers of zero to halve of local GDP (the bulk of all counties), there is a visible relationship between the extent of the grant relative to local GDP and income levels (Figure 10, Panel A). However, once grants account for more than halve of local GDP, reaching in a few cases over $200 \%$ of local GDP, other factors become more important in determining grants. For these counties grants are not closely relative to local GDP per capita (Figure 10, Panel B).

In practice, compensation grants have tended to reduce the extent of fiscal discrepancies over time. While the major losers from the 1994 tax reform were higher income areas, which therefore initially received more compensation, a $1 \%$ increase in per capita income is associated with only a $1 / 2$ per cent increase in compensation tax payments. Thus the compensation payment per unit of local GDP declines with rising income. In any event, poorer regions are now more dependent on compensation grants than richer ones are. At the level of the prefecture, for instance, the 50 prefectures with the lowest per capita GDP are twice as dependent on this form of transfer as the 50 prefectures with the highest income.

The total of all other transfers has a much stronger redistributive effect than the compensation transfer. At both the prefecture and the county level, there is a negative relation between this type of transfer and GDP per capita. The relationship is much stronger at the prefecture level than at the county level. In both cases, however, the overall explanatory value of income per capita in determining the level of transfers is low, indicating that there are many other variables that come into play when determining the scale of subnational transfers. 
Figure 10. Transfers as percent of county GDP and GDP per capita

2009

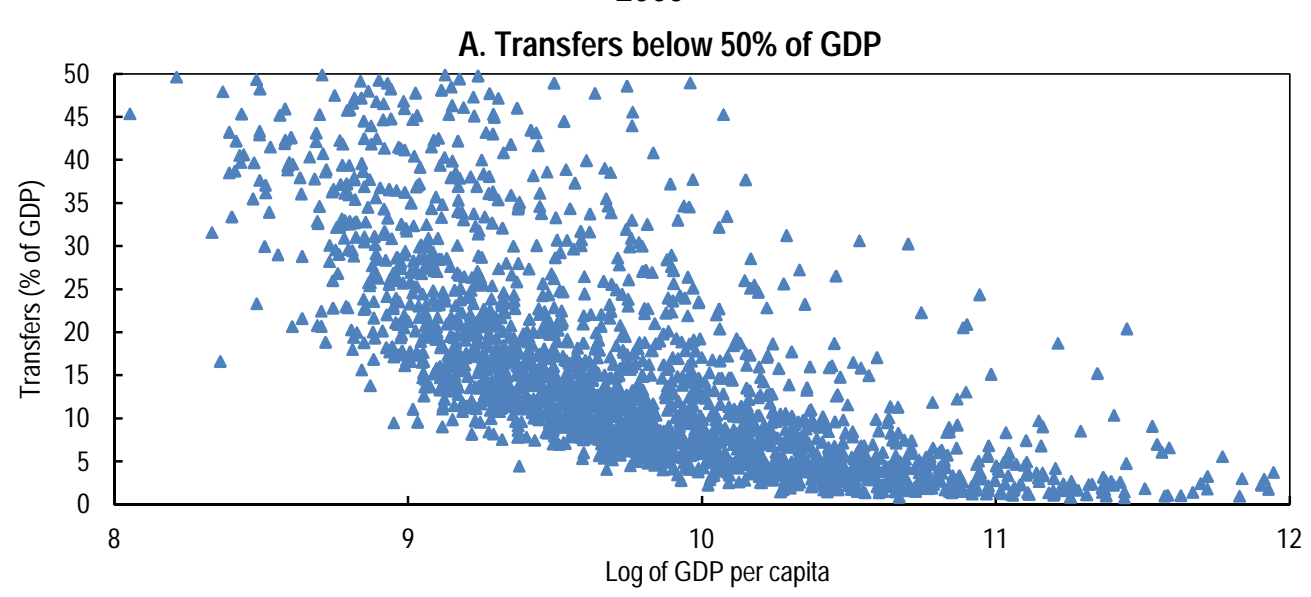

B. Transfers above $50 \%$ of GDP

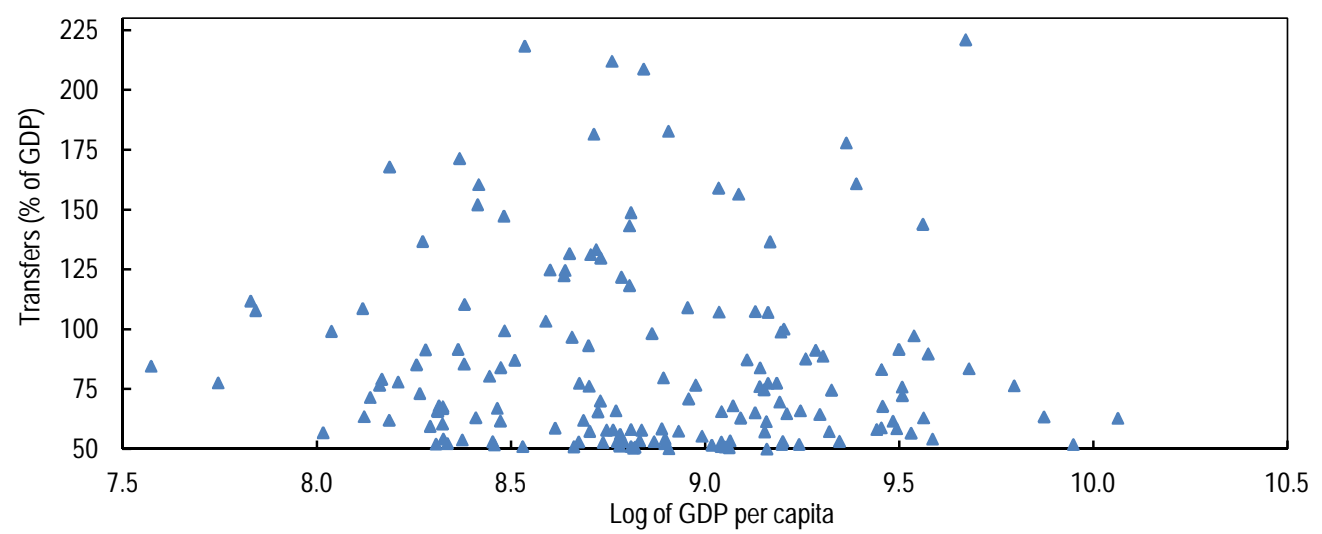

Source: OECD calculations and Ministry of Finance (2011a), 2009 Fiscal Statistics of Prefectures, Cities and Counties

At present, most weight is given to the registered population when determining the overall grant to a province. If the outcome of the allocation is measured in terms of the transfer per registered inhabitant in provinces, then there is no correlation between the income level of the province and the per capita grant received by the province (Figure 11, panel A). To a first approximation, then, the average grant is the same for each province on a per capita basis, with fluctuations according to the specific characteristics of the province. However, just as a flat-rate per capita tax is regressive, a flat rate per capita transfer is progressive, giving a higher increase in government revenue in poor provinces than in rich provinces. This result, however, is due entirely to the high level of transfers per registered inhabitant that are received by Beijing, Shanghai and Tianjin. Over the other 28 provinces and municipalities, there is a strong negative relationship between per capita GDP and the total transfer per registered inhabitant (Figure 11, panel B). 
Figure 11. Centre to province transfers and provincial GDP per capita

A. Per registered inhabitant

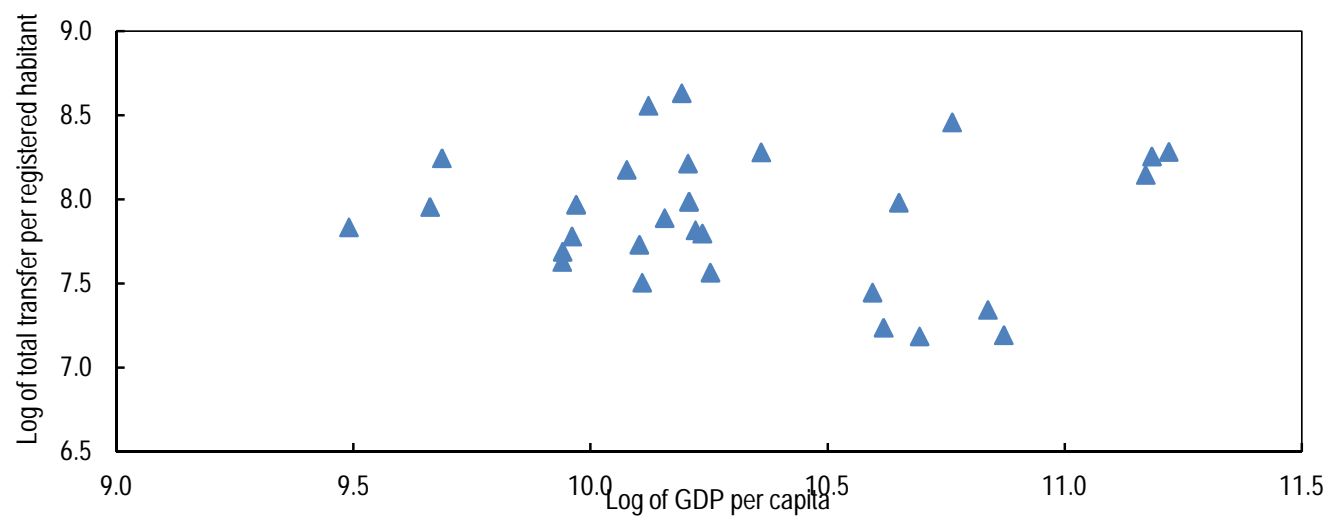

B. Per inhabitant

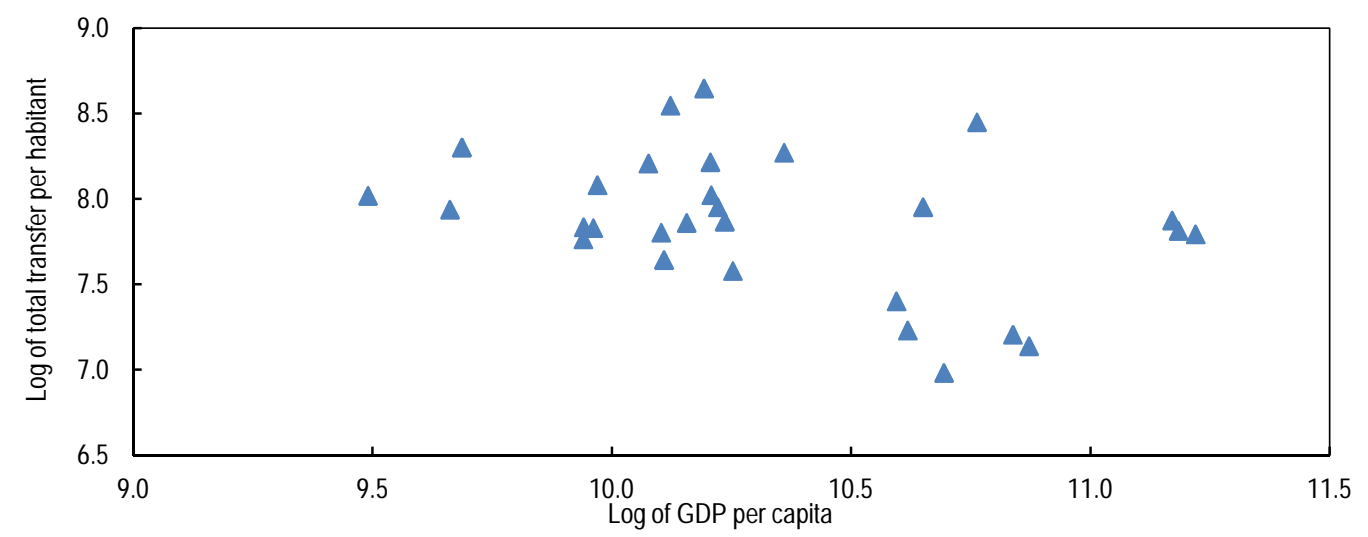

Note: The provinces of Tibet and Qinghai have been excluded due to the extreme values of their transfers.

Source: Ministry of Finance, Fiscal Statistical Yearbook of China 2011 and 2001.

The method of calculating the equalisation grant was changed in 2012 to take the number of migrants into account. The population used to calculate the per capita data was defined as the registered population plus $15 \%$ of the difference between the actual and the registered population. This change will tend to reduce the extent to which inter-provincial redistribution via transfers is correlated with income. However, the equity of spending within provinces could be improved if provinces followed the same rules in making their grants and higher transfers resulted in more spending on services for migrants.

\section{The use of earmarked transfers}

Intergovernmental transfers can serve several objectives (Oates, 1999; Ahmad and Searle, 2005; Blöchliger and Vammalle, 2009; OECD/KIPF, 2012). Three goals stand out:

- Fiscal equalisation across jurisdictions for public service provision.

- Correction of negative and positive spillovers to induce the right amount of services.

- Provision of certain types and standards of services as determined by the central government.

Achieving these goals requires the combined use of "unconditional grants" (general transfers), and "conditional grants" (earmarked transfers). The trade-off is complicated, with unconditional grants providing more local autonomy but requiring local capacity and accountability, and conditional grants giving the central government more control to meet its objectives (OECD, 2012 and Blöchliger and 
Vammalle, 2010). In practice, the share of unconditional versus conditional grants in China is well within the (very wide) ranges observed in the OECD (Figures 12 and 13). This share has remained broadly stable over the past decade.

Figure 12. Composition of grants for states/provinces in OECD countries

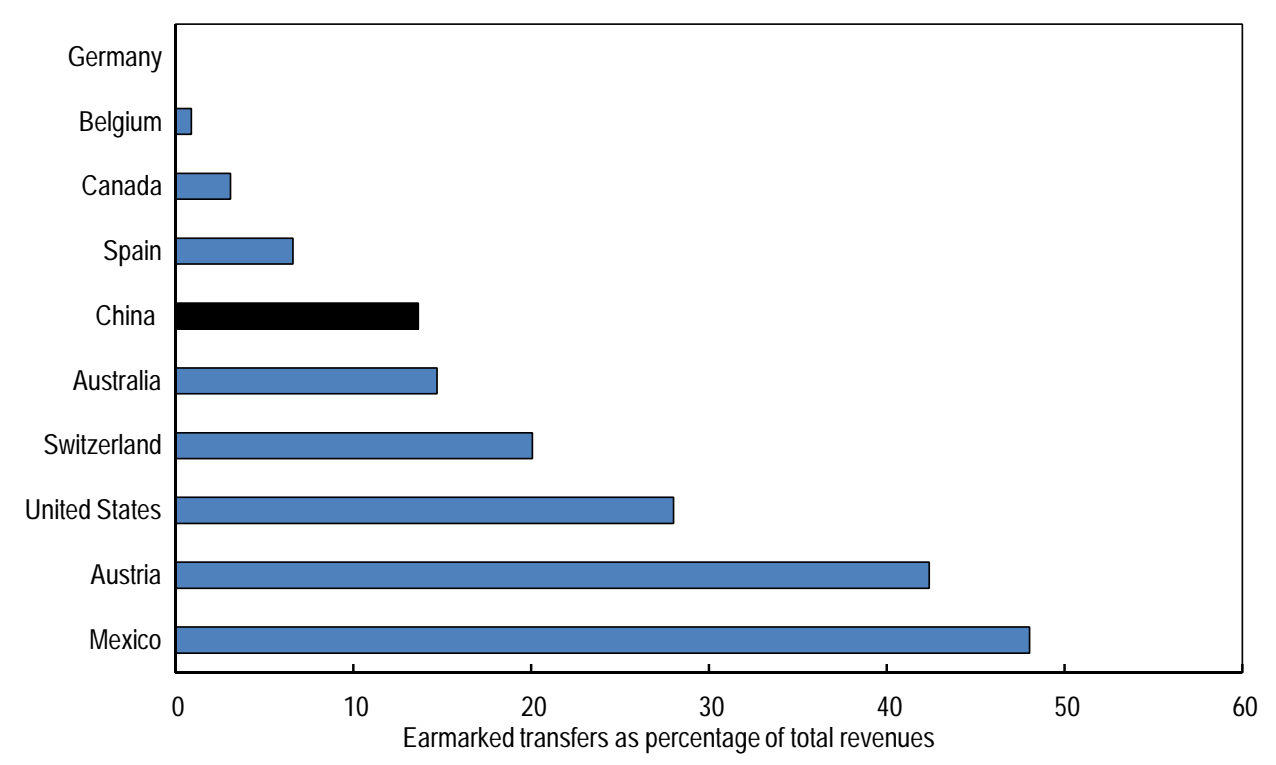

Note: 2006 data are used for OECD countries and 2011 data for China.

Source: OECD Fiscal Decentralisation Database; Ministry of Finance (2012), the Financial Statement of 2011 budget.

Figure 13. Composition of grants to local/sub-provincial level in OECD countries and China

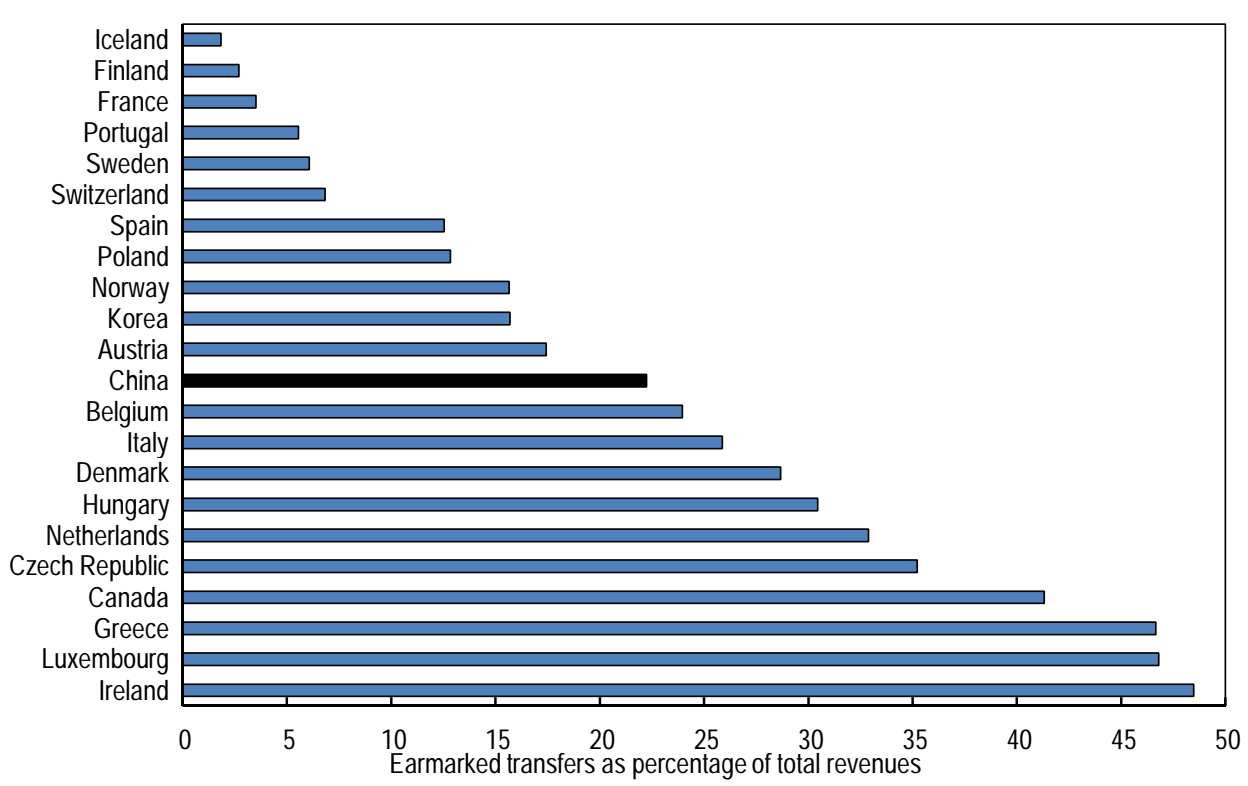

Note: 2006 data are used for OECD countries except Canada, Sweden and Poland. 2011 data is used for China..

Source: OECD Fiscal Decentralisation Database; Ministry of Finance (2012), the Financial Statement of 2011 budget. 
There are over 100 different types of earmarked grants, all of which are allocated on an ad hoc or negotiated basis (Ministry of Finance, 2012b). Moreover, many of the grants are determined by individual ministries and are not controlled by the Ministry of Finance. This undermines transparency relative to a rule-based system. In particular, the system favours localities that lobby harder rather than those in greater need. Furthermore, the centre lacks the monitoring mechanisms to ensure the effective use of these earmarked resources, especially at sub-provincial levels (Ahmad et al., 2004; Shen et al., 2012).

\section{The impact of the transfer system on fiscal inequality}

China's transfer policy has become markedly more redistributive over the past decade. By 2010, the reduction in the inter-provincial inequality through transfers was larger in China than in the OECD area (Table 10). The correlation between transfers per capita and GDP per capita, which was positive in 2000, had turned markedly negative by 2010. Despite the reduction in spending inequality, the fiscal disparity per capita is high in China as compared with OECD countries. However, there is markedly less inequality in fiscal spending than in GDP per capita.

Table 10. Fiscal disparity reducing effect of transfers in OECD countries and in China

\begin{tabular}{lcccc}
\hline & \multicolumn{3}{c}{ After equalisation (in per cent) } & $\begin{array}{c}\text { Equalisation } \\
\text { effect }\end{array}$ \\
\cline { 2 - 5 } & $\begin{array}{c}\text { Gini } \\
\text { coefficient }\end{array}$ & $\begin{array}{c}\text { Highest } \\
\text { capacity }\end{array}$ & $\begin{array}{c}\text { Lowest } \\
\text { capacity }\end{array}$ & $\begin{array}{c}\text { Gini } \\
\text { coefficient }\end{array}$ \\
\hline Federal/regional countries & & & & \\
Australia & 0.00 & 100 & 100 & 0.05 \\
Canada & 0.07 & 157 & 93 & 0.03 \\
Germany & 0.02 & 105 & 97 & 0.04 \\
Italy & 0.10 & 115 & 89 & 0.11 \\
Spain & 0.04 & 117 & 84 & 0.11 \\
Switzerland & 0.11 & 159 & 64 & 0.04 \\
\hline Unitary countries & & & & \\
Denmark & 0.04 & 175 & 86 & 0.04 \\
Finland & 0.03 & 105 & 95 & 0.08 \\
Norway & 0.05 & 118 & 93 & 0.08 \\
Portugal & 0.14 & 138 & 65 & 0.20 \\
Sweden & 0.03 & 114 & 88 & -0.01 \\
Turkey & 0.06 & 107 & 64 & 0.16 \\
\hline OECD unweighted average & $\mathbf{0 . 0 5}$ & $\mathbf{1 2 4}$ & $\mathbf{8 6}$ & $\mathbf{0 . 0 9}$ \\
China (2010) & 0.18 & 273 & 51 & 0.13 \\
China (2000) & 0.25 & 391 & 41 & 0.07 \\
\hline
\end{tabular}

1. For federal/regional countries the indicators are calculated for the state/regional level and include every single jurisdiction. For unitary countries, local governments are grouped into deciles (or "tenths") ranked in increasing order of fiscal capacity before equalisation. Both sections of the table show the Gini coefficients of fiscal capacity across sub-central governments, and the maximum and minimum fiscal capacity before and after receiving transfers. Year 2004 figures are used for OECD countries, except Germany (2005).

2. China follows the calculation method of Federal countries. Its Gini coefficient is calculated based on provincial-level fiscal data, weighted by population size.

Source: Blöchliger and Charbit, 2008; Ministry of Finance (2011), Fiscal Statistical Yearbook of China 2011 and 2001; Statistics Sweden.

\section{Revenue disparities within provinces have been reduced}

The large disparities within provinces have also been narrowed by intergovernmental transfers in recent years. This finding contrasts with the general observation in the literature that the transfer system had not reduced fiscal disparities at the sub-provincial level (Liu and Shih, 2004; Tsui, 2005; Zhang and Zheng, 2010). This is at least partly because few of these studies rest on recent data. By 2009, the overall redistributive effects of the transfers at the prefecture and county/district levels had become quite strong. For instance, transfers reduced the Theil index across all levels of sub-national government by $65 \%$ while 
the Gini coefficient was reduced from 0.53 to 0.32 (Table 11). The fall in national fiscal inequality has been driven by a fall of within-province inequality at the county level.

Table 11. The impact of transfers at sub-provincial levels on inequality of revenue

\begin{tabular}{|c|c|c|c|c|c|c|}
\hline \multicolumn{7}{|c|}{ In 2009} \\
\hline & \multicolumn{2}{|c|}{ All sub-provincial units } & \multicolumn{2}{|c|}{$\begin{array}{l}\text { Prefecture-level cities and } \\
\text { districts }\end{array}$} & \multicolumn{2}{|c|}{$\begin{array}{c}\text { Counties and county-level } \\
\text { cities }\end{array}$} \\
\hline & $\begin{array}{l}\text { Inequality } \\
\text { index }\end{array}$ & $\begin{array}{l}\text { Reduction in } \\
\text { inequality } \\
\text { due to } \\
\text { transfers }\end{array}$ & $\begin{array}{l}\text { Inequality } \\
\text { index }\end{array}$ & $\begin{array}{l}\text { Reduction in } \\
\text { inequality } \\
\text { due to } \\
\text { transfers }\end{array}$ & $\begin{array}{l}\text { Inequality } \\
\text { index }\end{array}$ & $\begin{array}{l}\text { Reduction in } \\
\text { inequality } \\
\text { due to } \\
\text { transfers }\end{array}$ \\
\hline \multicolumn{7}{|l|}{ Theil index } \\
\hline Between provinces & 0.06 & 0.06 & 0.02 & 0.06 & 0.08 & 0.05 \\
\hline Within-province & 0.12 & 0.27 & 0.06 & 0.08 & 0.10 & 0.23 \\
\hline Country-wide & 0.18 & 0.33 & 0.08 & 0.14 & 0.18 & 0.29 \\
\hline Gini coefficient & 0.32 & 0.21 & 0.23 & 0.14 & 0.31 & 0.19 \\
\hline
\end{tabular}

Source: OECD calculation based on Ministry of Finance (2011a), 2009 Fiscal statistics of prefectures, cities and counties.

Nevertheless, disparities within provinces remain high. Despite the great efforts in reducing disparities within provinces, the sub-provincial Gini coefficient remains at 0.32 , much higher than the 0.18 at the provincial level (Table 10). Across prefectures regional inequality is quite low. On the other hand, they do not appear to have been as successful in reducing fiscal inequalities in the counties for which they are responsible. One particular problem for county governments is that earmarked transfers often require matching funds which may not be available at county level.

The extent of fiscal equalisation within a province varies across provinces. High provincial income levels are not associated with low intra-province inequalities, and vice versa (Figure 14). For instance, the coastal provinces of Guangdong, Jiangsu and Shandong display high incomes and high inequality. Even so, overall, between 2000 and 2010, there was a marked reduction in within-province inequality: the provinces with the highest initial fiscal inequality registered the largest drops (Figure 15).

Figure 14. Fiscal inequality within provinces by province

Gini coefficient of fiscal revenue per capita, provinces ordered by level of per capita GDP

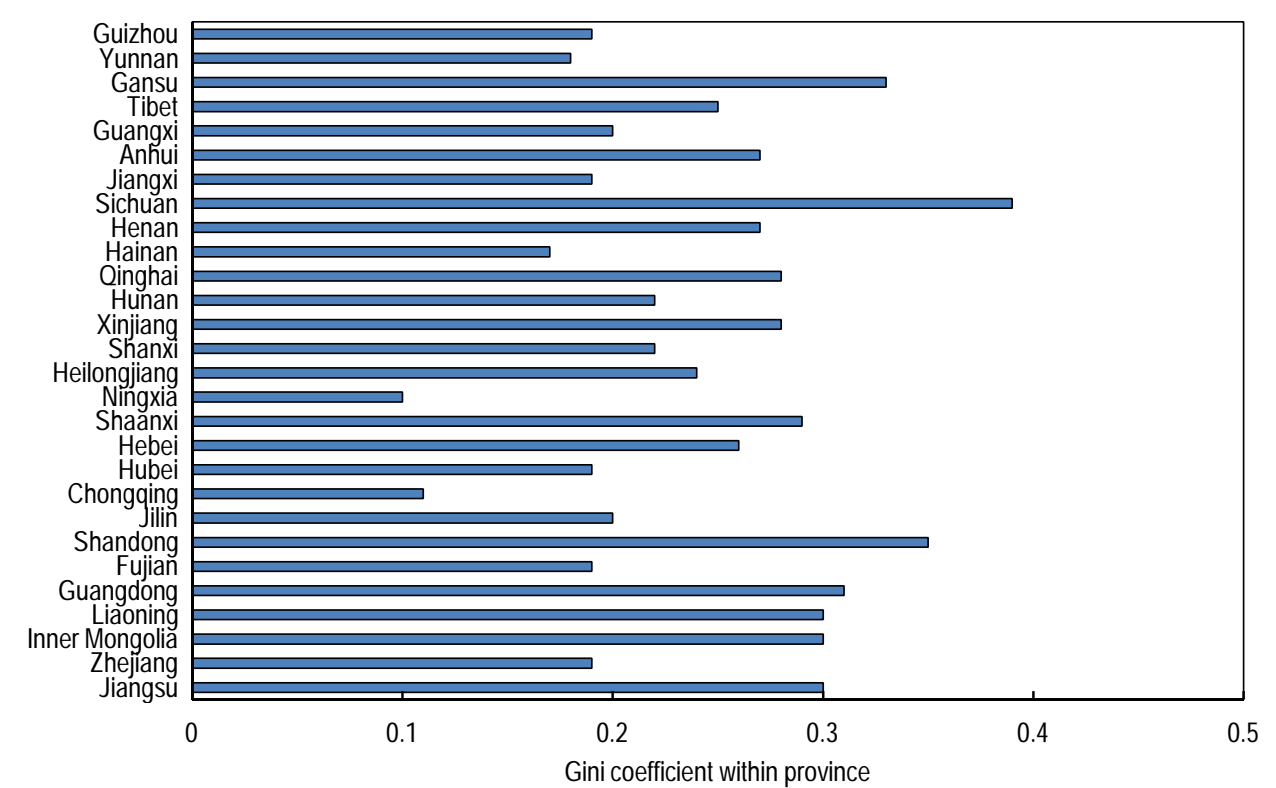

Source: OECD calculation based on Ministry of Finance (2011a), 2009 Fiscal statistics of prefectures, cities and counties. 
ECO/WKP(2013)22

Figure 15. The reduction of intra-provincial fiscal inequality and the initial level of inequality Inequality is measured by the Gini index

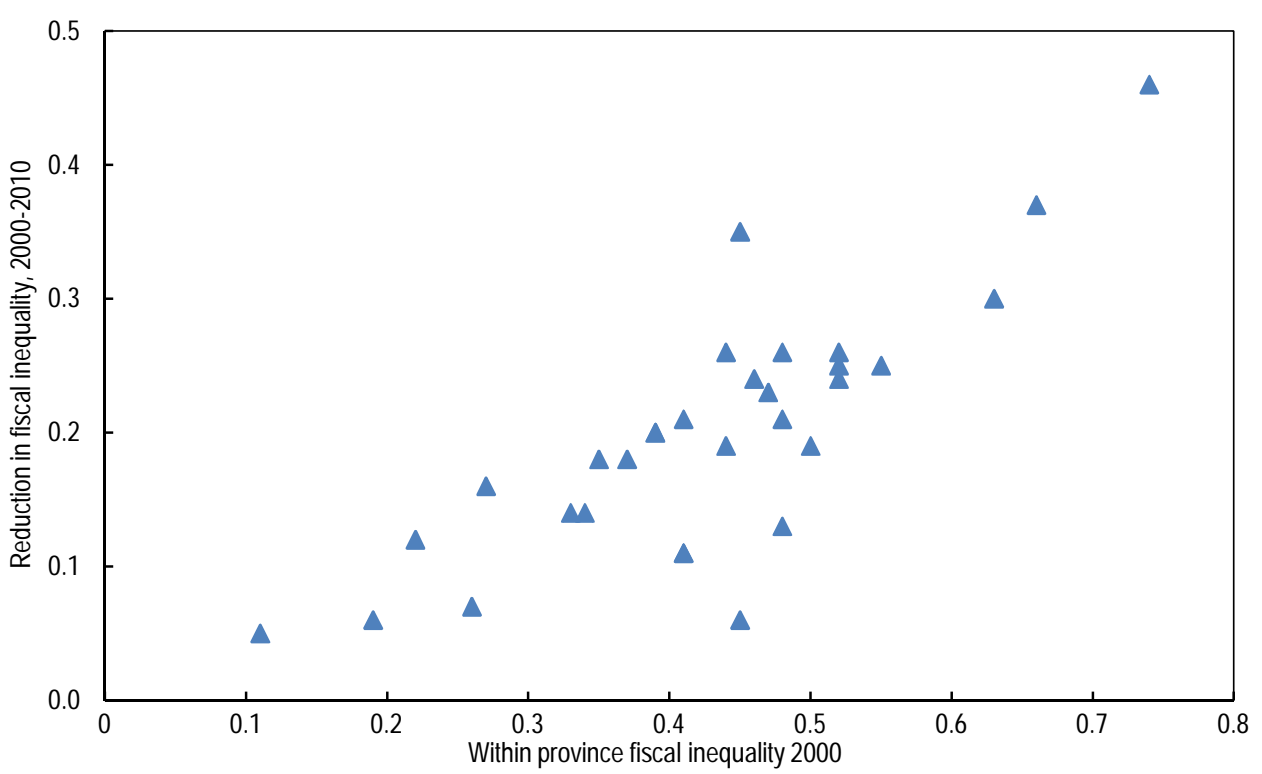

Note: The reduction in inequality is measured as the change in the Gini index between 2000 and 2009 .

Source: OECD calculation based on Ministry of Finance (2011a), 2009 Fiscal statistics of prefectures, cities and counties.

\section{Within provinces disparities in spending and service provision}

In many sectors, the delivery of public services largely depends on the number people employed in particular service areas. The bulk of local public spending on education, healthcare and general public services are salaries paid to civil servants, teachers, doctors and government administrative staff. Across provinces, there is much less disparity in the number of government employees than in overall spending (Figure 16, panel A). The dispersion in public spending within a province does not appear to be associated with the level of income (Figure 16, Panel B). The dispersion of spending within a province does, however, appear to be correlated with the dispersion of government employment (Figure 16, Panel C). However, the dispersion of government employment within a province is extremely low - a Gini coefficient of around 0.03 seems typical. This might indicate that basic services are being provided on an equal basis, certainly on a much more equal basis than the expenditure data would suggest. 
Figure 16. Dispersion of government spending and employment across and within provinces

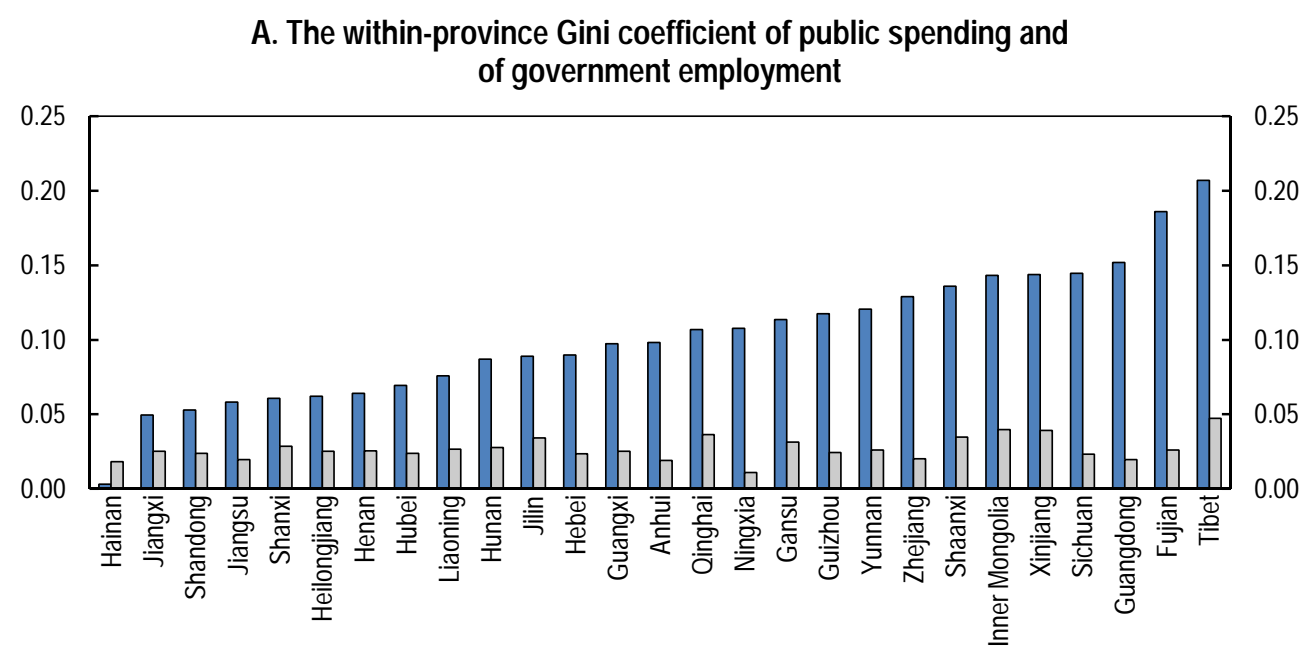

$\square$ Gini of Public spending per capita within a province $\square$ Gini of civil servants number per capita within a province

B. Provincial GDP per capita and the Gini coefficient of public spending within a province

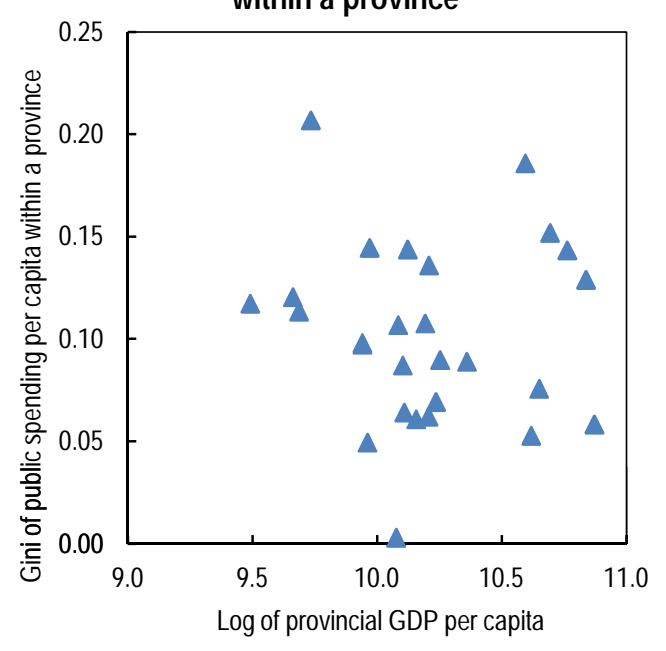

C. The within-province Gini coefficient of public spending and of government employment

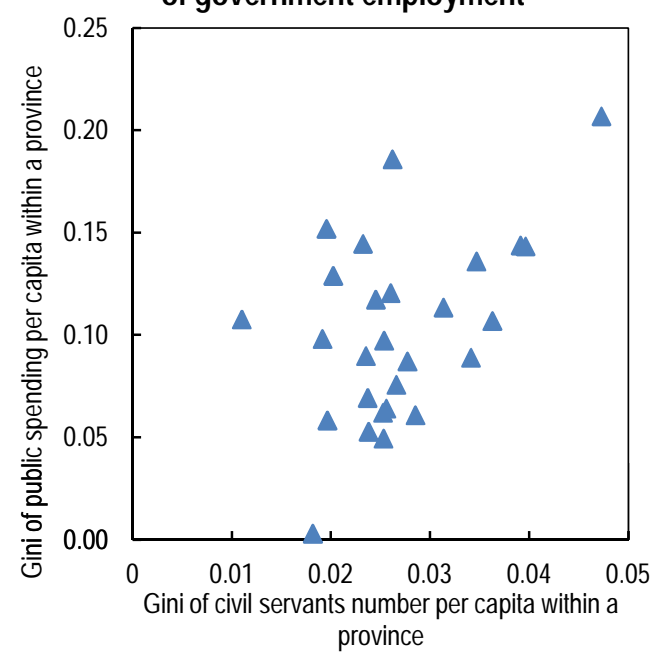

Source: Ministry of Finance (2011b), Local Fiscal Statistical Yearbook, 2009.

\section{Government policies aim at improving sub-national finance}

\section{The national service equalisation plan}

Equalising basic public services across the country is a national strategic goal. It is now seen as one of the fundamental goals for building a harmonious society through scientific development (CCP, 2006). In 2012, the government set out a five year plan for improving basic public services that would form the basis for equalising basic public services for everyone by 2020 (Table 12). Specifically, the plan stresses the need to further reduce the impact of regional disparities on the provision of basic services in order to equalise access to services whether the person lives in an urban or a rural area. The Plan sets the scope, standard and mechanism to deliver such services in public education, labour and employment services, 
social security, social services, health care, population and family planning services and housing services, as well as those related to culture and sports.

Table 12. The $12^{\text {th }}$ Five Year Plan for basic public service equalisation and urbanisation

\begin{tabular}{|c|c|}
\hline Category & Scope and examples \\
\hline Basic education & $\begin{array}{l}\text { Increase spending and improve nine-year compulsory education quality in lagging regions. } \\
\text { Equalise salary standards for teachers across the jurisdiction of a county or city. Ensure } \\
\text { equal education for migrant children. Provide subsidies, scholarship or exempt fees for } \\
\text { children from poor families. }\end{array}$ \\
\hline $\begin{array}{l}\text { Basic employment } \\
\text { service }\end{array}$ & $\begin{array}{l}\text { Aim to make basic services such as job search, information dissemination and aid to self- } \\
\text { employment free in order to facilitate equal job opportunities. Provide assistance and } \\
\text { subsidies to poor families for finding jobs and vocational training. Basic services such as } \\
\text { the coordination of labour relations, consultation of laws, legislative consultation service, } \\
\text { labour security monitoring and dispute mediation should be provided free of charge. }\end{array}$ \\
\hline Basic social services & $\begin{array}{l}\text { Improve social assistance for the elderly, disabled, and orphans. Increase pension } \\
\text { payments and provide better life support and care for the elderly. Ensure acceptable living } \\
\text { standard for ex-servicemen. }\end{array}$ \\
\hline $\begin{array}{l}\text { Basic medical and } \\
\text { health care }\end{array}$ & $\begin{array}{l}\text { Increase gradually healthcare spending per capita. Improve healthcare quality in hospitals } \\
\text { and clinics in counties, townships and villages. Ensure medicine supply in village clinics. } \\
\text { Equalise basic public health services (health records monitoring, health related education, } \\
\text { vaccination, communicable disease prevention). }\end{array}$ \\
\hline Basic housing & $\begin{array}{l}\text { Increase the supply of low-cost rental housing and affordable housing for poor urban } \\
\text { households and migrant workers. Renovate shanty towns and dilapidated buildings in rural } \\
\text { areas. Improve management capacity for affordable housing. }\end{array}$ \\
\hline es tor the & Increase subsidy assistance and improve services for disabled. \\
\hline
\end{tabular}

disabled

Social insurance Increase pension coverage, especially for migrant workers, self-employed and other notcovered residents. Improve pension support for landless peasants. Achieve basic pension management at the national level. Increase healthcare insurance coverage, especially for migrants and self-employed. Achieve higher repayment ratio in clinics than in hospitals. Improve cross-province healthcare repayment mechanism. Also increase the coverage for other types of social insurances (unemployment, work-related injuries, maternity insurance).

Public culture and Improve cultural services for villages and regions in central and western China. Increase sports the coverage of radio and television in villages. Provide more free of charge publications and books in rural areas and small cities. Improve sports access for the general public.

Convert migrants into Encourage local registration conversion for migrants who satisfy the criteria (e.g. having urban residents stable jobs in cities). Improve education, pension, healthcare and housing service for migrants who do not satisfy the criteria.

\begin{tabular}{ll}
\hline $\begin{array}{l}\text { Improve infrastructure } \\
\text { in cities }\end{array}$ & $\begin{array}{l}\text { Comprehensively increase infrastructure investment for public transport, } \\
\text { telecommunication, supply of energy and water, sewage and waste treatment in cities. }\end{array}$ \\
\hline
\end{tabular}

Source: State Council (2012), www.gov.cn/zwgk/2012-07/20/content_2187242.htm. National People's Congress (2011), the 12 ${ }^{\text {th }}$ National Five-Year Plan on Social and Economic Development, news.xinhuanet.com/politics/2011-03/16/c_121193916.htm

In particular, the Plan addresses the issue of migrants, echoing the national policy framework on promoting sound urbanisation. The central government demands sub-national governments to improve public services for migrants in the areas of education, pension, healthcare and housing. Moreover, the urbanisation framework identifies the improvement of urban infrastructure as a priority, given the existing deficit in provision (Herd et al., forthcoming).

To achieve the service delivery target, the Plan calls for improving public finances by:

- clearly defining intergovernmental assignments and spending responsibilities across government tiers, and in particular assign pension and healthcare spending to provincial governments;

- improving the intergovernmental transfer system, by increasing the percentage of general transfers and increasing the percentage of rules-based transfers and raising their amount especially at sub-provincial levels; 
- $\quad$ promoting a sound public finance supporting system, by allocating certain profits from SOEs to service provision and improving the fiscal resources available to counties;

- prioritising spending on health and social protection rather than "economic activities".

The government has highlighted the use of general transfers as means of increasing equality of access to basic public services. This could involve, for example, grouping different earmarked project grants on education together into a block general purpose grant allocated to education. Local government would receive broad targets from higher governments rather than specific requirement to spend the money on specific elements in education. The number of such general purpose transfers has increased in the past few years and most involve some form of differentiation according to the relative income level of the province or its geographic location. Another approach would be to increase the size of the general grants whose most important element is funded by allocating the funds raised by the tax on personal incomes.

\section{Property taxation}

The introduction of taxation on residential property has been under consideration since 2003 as a means of improving local tax revenue. China does have both property and land taxes but they do not apply to residential real estate. The government has considered introducing a new residential property tax that might be used either to raise local spending or to reduce the reliance of local governments on transfers from higher levels of government. Most local governments in the OECD raise revenues from recurrent taxation on residential property in their area. This form of taxation provides a linkage between the level of local taxation and the provision of local services. It is a more common form of local taxation than local income or sales taxes as property cannot be moved whereas the tax base for a sales tax or an income tax can easily move. From the point of view of resource allocation, if the property tax can be levied exclusively on land rather than on the building on the land, then such a tax is one of the least distortionary taxes.

Five types of taxes are levied on property and land transactions in China (Table 13). Using the OECD classification of taxes, only two of these would be classified as property taxes as they are levied annually and based on the ownership of property. Such taxes have not been levied on residential property since 2007. Two of the other taxes are based on transactions either of property or land (but only when the land changes use from agricultural to constructed land). In addition, there is a special capital gains tax that applies only to land transactions. The tax on property transactions is one of the few taxes for which a provincial government can set the rate ( 23 set the rate at $3 \%$, six at $4 \%$ and two at $5 \%$ ). In addition, if a property in held for less than five years it is subject to the business tax at a rate of $5.5 \%$ on the sale of the property.

Table 13. Characteristics of taxes on land and property

\begin{tabular}{|c|c|c|c|c|}
\hline Tax & $\begin{array}{r}\text { Date of } \\
\text { introduction }\end{array}$ & Tax base & Tax rate & Collection stage \\
\hline \multicolumn{5}{|l|}{ Taxes based on use } \\
\hline Real estate tax & 1986 & Real estate for business use & $\begin{array}{l}1.2 \% \text { of original value or } 12 \\
\text { of rental income }\end{array}$ & Possession \\
\hline Urban land-use tax & 1988 & $\begin{array}{l}\text { Taxable land size (not paid by } \\
\text { households since } 2007 \text { ) }\end{array}$ & CNY $30 / \mathrm{m}^{2}$ to $0.6 / \mathrm{m}^{2}$ & Possession \\
\hline \multicolumn{5}{|l|}{ Transaction-based taxes } \\
\hline Land appreciation tax & 1994 & Land appreciation value & $\begin{array}{l}\text { Progressive tax rate ( } 30 \text { to } \\
60 \% \text { on appreciation value) }\end{array}$ & Transaction \\
\hline $\begin{array}{l}\text { Tax on the use of arable } \\
\text { land }\end{array}$ & 1987 & $\begin{array}{l}\text { Quantity of arable land } \\
\text { converted to building land }\end{array}$ & CNY $1-10 / m^{2}\left(5-50 / m^{2}\right.$ after & $\begin{array}{r}\text { Land } \\
\text { development }\end{array}$ \\
\hline Tax on property contracts & 1997 & $\begin{array}{l}\text { Self-reported value of land and } \\
\text { house transfer }\end{array}$ & $3 \%$ to $5 \%$ & Transaction \\
\hline
\end{tabular}


The recurrent property tax is levied only on commercial property. There are two formulae for calculating the tax burden: one applies a rate of $1.2 \%$ to the original value of the property less a depreciation deduction of between 10 and $30 \%$; the other is based on $15 \%$ of the rent generated by the property. The urban land-use tax is based on a flat rate per occupied square metre. These two taxes are of much less importance to the government as a source of revenue than in the OECD area (Figure 17). A number of OECD countries raise between 3\% and 4\% of GDP in recurrent property taxes. Only four OECD countries raise less than in China, where such recurrent taxes amount to $0.5 \%$ of GDP (Table 14). The low yields are a reflection of the absence of taxation on residential real estate and of the fact that the tax on urban land use is not based on market values.

Figure 17. Transactions and recurrent property taxation

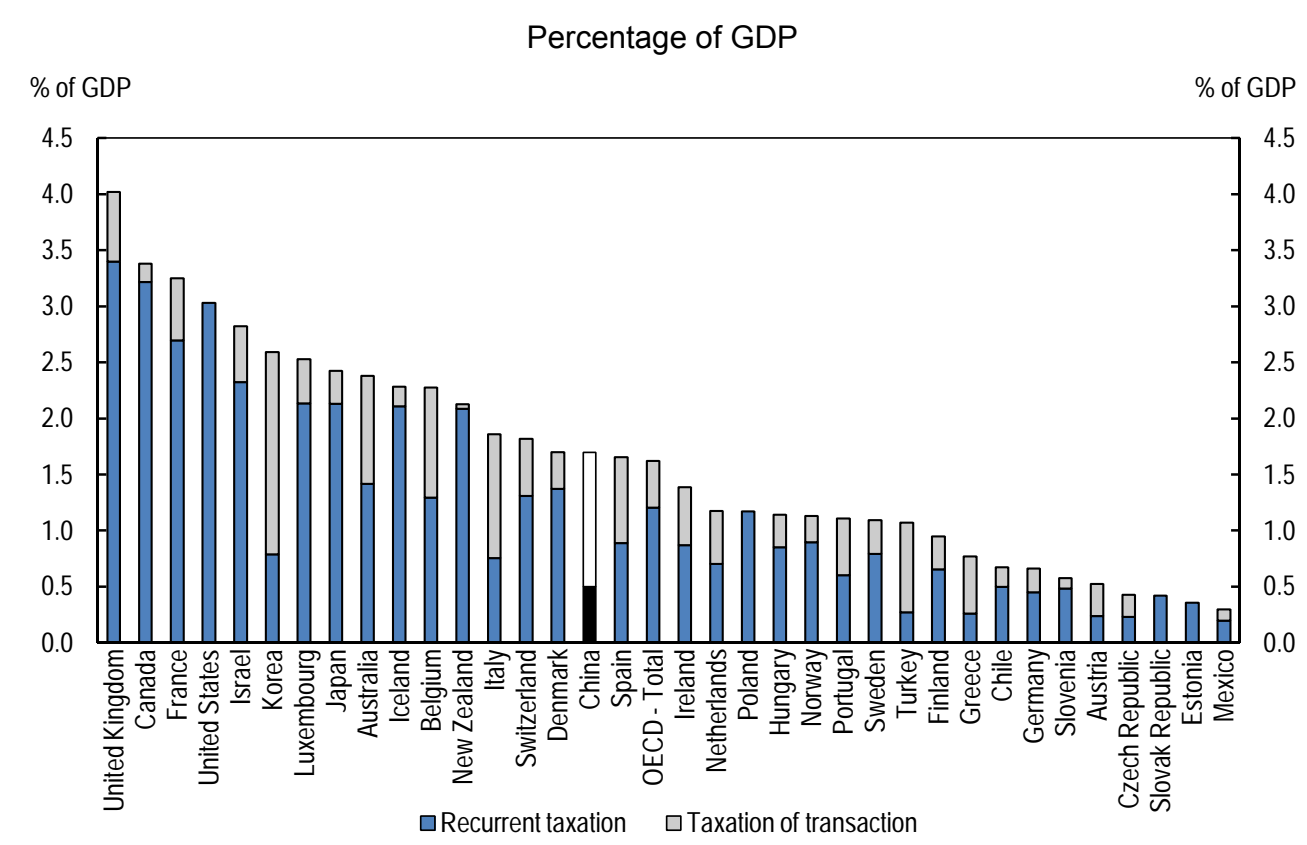

Source: OECD Revenue Statistics and China Statistical Yearbook.

Table 14. Breakdown of property and land tax revenue

In per cent of GDP

\begin{tabular}{cccccc}
\hline & $\mathbf{2 0 0 7}$ & $\mathbf{2 0 0 8}$ & $\mathbf{2 0 0 9}$ & $\mathbf{2 0 1 0}$ & $\mathbf{2 0 1 1}$ \\
\hline Land and property related taxes & 1.0 & 1.2 & 1.4 & 1.6 & 1.7 \\
Tax on use & 0.3 & 0.5 & 0.5 & 0.5 & 0.5 \\
Real estate tax & 0.2 & 0.2 & 0.2 & 0.2 & 0.2 \\
Urban land-use tax & 0.1 & 0.3 & 0.3 & 0.3 & 0.3 \\
Tax on transactions & 0.8 & 0.7 & 0.9 & 1.1 & 1.2 \\
Land appreciation tax & 0.2 & 0.2 & 0.2 & 0.3 & 0.4 \\
Tax on the use of arable land & 0.1 & 0.1 & 0.2 & 0.2 & 0.2 \\
Tax on property contracts & 0.5 & 0.4 & 0.5 & 0.6 & 0.6 \\
\hline
\end{tabular}

Source: Ministry of Finance. 
Two municipalities are piloting a recurrent tax on residential property. However, the design of these pilots is very restrictive with nearly all property exempted from paying the tax. In the first full year of the trial, the taxes raised only CNY 100 million and CNY 300 million in Chongqing and Shanghai respectively $(0.00001 \%$ and $0.000015 \%$ of Gross Regional Product in the areas concerned).

Besides the recurrent tax on property there are also taxes on property transactions. If the tax on land appreciation is a regarded as a tax on property, then China raises $1.2 \%$ of GDP from property transactions - four times the level in the OECD area. The yield is so high because property values are much higher relative to incomes in China than in the OECD area, and because the number of transactions is high due to the high rate of house construction. These factors more than offset the low level of second-hand property transactions and the relatively low rate of the transactions tax. Overall, the sum of taxation on transactions and usage in China (at 1.7\%) of GDP is only slightly below the OECD average of $2.0 \%$ of GDP (Figure 17). However, the structure is more economically damaging in that it hinders turnover in the market, though the tax on land is economically efficient.

Introducing a nationwide residential property tax would exacerbate differences in fiscal revenue across provinces. Past experience suggests that the tax rate would be uniform across the country. In this case, the revenue for the property tax would mainly accrue to prefectural-level cities and their districts, where the bulk of property is situated. Moreover, the level of property prices is highly correlated with the level of per capita income (in 2011, a 1\% increase in per capita GDP was associated with a $0.7 \%$ increase in the average selling price of new property). Thus the property tax would accrue to the local authorities that rely least on transfers from central and provincial governments.

The government also faces a dilemma in considering the introduction of a residential property tax. Potential property buyers will estimate the present value of future property taxes and reduce the price they are willing to pay by this discounted value. In turn this will reduce the price of the land-use right. But local governments own all land and rely on the sale of new land-use rights to finance urban infrastructure.

Local authorities would probably lose revenue by introducing a residential property tax, at least while the expansion of urban areas continues. If property taxes were set at a level such that annual revenues rose to the average level in the OECD area, then the property tax rate would need to be set at $1 \%$ of the market value of properties as urban property values are equivalent to 1.25 times GDP. Assuming a real discount rate of $4 \%$, this would lower house prices by $25 \%$ and land prices by $50 \%$, given the average share of land in property prices. In 2012 the gross revenue from land sales amounted to just over 5\% of GDP, so the fall in revenue from land-use rights would likely outweigh the increase in receipts from the property tax. Moreover, land-lease income accrues immediately to local governments' revenue, while it takes time to realise the anticipated level of property taxation in that tax rate and coverage could only be raised gradually from the level set in the pilot cases. Given that urbanisation is far from complete, local authorities have an interest to maintain the current system of land sales and no property tax at least until the process of urbanisation is nearly complete. At that point land sales will be much less important as a source of revenue. Over the longer term, property taxation would then represent a stable source of revenue - albeit one that would mainly accrue to the governments of richer areas.

\section{Conclusion}

The main features of China's current sub-national finance arrangements date back to the 1994 tax reform. China has a multi-level government structure that shares national tax revenues through a system of tax sharing and transfers, and divides spending assignments and responsibilities. Local governments have hardly any discretionary power to modify taxation and are effectively agents acting on behalf of the central government in expenditure decisions, though they have some non-tax revenue from fees, levies and penalties. They can spend the profit from the sale of land-use rights subject to restrictions set by the central 
government. As the 1994 tax reform recentralised revenues and decision-making power, vertical gaps between revenue and expenditure at sub-national levels have grown. In order to accommodate a strong increase in the share of expenditure in the areas covered by sub-national government that has not been matched by increased tax revenues, the central government has increased the scale of the transfer system. Over the past decade, China's transfer policy has addressed the horizontal imbalances and become markedly more redistributive. Nevertheless, fiscal disparities within provinces remain high and are much greater than between regions in OECD countries. The extent of fiscal equalisation within provinces varies, thus affecting the delivery of services. The government's plan to equalise service provision across the country therefore calls for fine-tuning the intergovernmental transfer system and improving local revenue. Some local governments are testing a residential property tax but not in a form that would substantially raise tax revenue. A significant property tax would tend to lower the revenue from the sale of land-use rights and would, in general, improve the fiscal position of those local governments that already have strong budgets.

\section{BIBLIOGRAPHY}

Ahmad, E., R. Singh and M. Fortuna (2004), "Toward More Effective Redistribution: Reform Options for Intergovernmental Transfers in China", IMF Working Papers, WP/04/98.

Ahmad, E. and B. Searle (2005), "On the Implementation of Transfers to Subnational Governments", IMF Working Papers, WP/05/130.

Ansolabehere, S. and J. M. Snyder (2006), "Party Control of State Government and the Distribution of Public Expenditures", Scandinavian Journal of Economics, Vol. 108.

Brys, B. and S. Matthews (2013), “Tax Policy and Tax Reform in the People's Republic of China”, OECD Taxation Working Papers, forthcoming.

Blöchliger, H. and C. Charbit (2008), "Fiscal Equalisation”, OECD Journal: Economic Studies, Vol. 2008/1.

Blöchliger, H. and J. Rabesona (2009), "The Fiscal Autonomy of Sub-Central Governments”, OECD Working Papers on Fiscal Federalism, No. 9.

Blöchliger, H. and O. Petzold (2009), "Taxes and Grants: On the Revenue Mix of Sub-Central Governments", OECD Working Papers on Fiscal Federalism, No. 7.

Blöchliger, H., M. Brezzi, C. Charbit, M. Migotto, J. M. Pinero Campos and C. Vammalle (2010), "Fiscal Policy Across Levels of Government in Times of Crisis", OECD Working Papers on Fiscal Federalism, No. 12.

Blöchliger, H., O. Merk, C. Charbit and L. Mizell (2007), "Fiscal Equalisation in OECD Countries", OECD Working Papers on Fiscal Federalism, No. 4.

Blöchliger, H. and Vammalle, C. (2009), "Grants Systems in OECD Countries: Trends and Some Policy Issues", Paper prepared for the KIPF Meeting in Copenhagen, September.

CCP (China Communist Party) (2006), Decision on Several Major Questions Regarding Establishing a Socialist Harmonious Society, Sixth central meeting of the $16^{\text {th }}$ Chinese Communist Party Committee (in Chinese). 
Herd, R., V. Koen and T. Chalaux (forthcoming), "Policies for Inclusive Urbanisation in China", OECD Economics Department Working Papers.

Huang, B. and K. Chen (2012), “Are Intergovernmental Transfers in China Equalizing?”, China Economic Review, Vol. 23.

Kamal-Chaoui, L., E. Leman and Z. Fufei (2009), "Urban Trends and Policy in China”, OECD Regional Development Working Papers, 2009/1.

Larcinese, V., L. Rizzo and C. Testa (2006), “Allocating the U.S. Federal Budget to the States: The Impact of the President", Journal of Politics, Vol. 68.

Li, P., H.C. Xu, and C. Li (2010), "Brief Illustration of the Fiscal System in China", China Fiscal and Economy Publishing (in Chinese).

Liu, M. and V. Shih (2005), "Gauging the Deficit and Welfare Effects of the 1994 Fiscal Reform at the County Level”, Forum for Economic Development Working Papers Series, No. FE20050090.

Ministry of Finance (2011a), 2009 Fiscal Statistics of Prefectures, Cities and Counties.

Ministry of Finance (2011b), Local Fiscal Statistical Yearbook, 2009.

Ministry of Finance (2012a), Fiscal Statistical Yearbook of China 2011.

Ministry of Finance (2012b), "Measures for the Equalisation Transfers in 2012", Budgetary Department, yss.mof.gov.cn/zhengwuxinxi/zhengceguizhang/201207/t20120725_669218.html (in Chinese).

Oates, W. (1999), “An Essay on Fiscal Federalism”, Journal of Economic Literature, Vol. 37.

OECD (2006a), Challenges for China's Public Spending: Toward Greater Effectiveness and Equity, OECD, Paris.

OECD (2006b), Economic Surveys: Germany, OECD, Paris.

OECD (2010), Economic Survey of China, OECD, Paris.

OECD (2012 forthcoming), Financing Green Growth in OECD countries, OECD, Paris.

OECD/KIPF (Korea Institute of Public Finance) (2012), Institutional and Financial Relations across Levels of Government, OECD Fiscal Federalism Studies, OECD Publishing.

Shen, C.L., J. Jin and H.F. Zou (2012) "Fiscal Decentralization in China: History, Impact, Challenges and Next Steps", Annals of Economics and Finance, Vol. 13.

State Council (2012), The National Comprehensive Plan for Basic Public Service System, www.gov.cn/zwgk/2012-07/20/content_2187242.htm (in Chinese), www.china.org.cn/china/201207/19/content_25950483.htm (in English).

Tsui, K. (2005), "Local Tax System, Intergovernmental Transfers and China's Local Fiscal Disparities", Journal of Comparative Economics, Vol. 33.

Zhang, L. and X. Zheng (2010), "The Determinants of Intergovernmental Transfer”, in Man, J. Y. and Y.H. Hong (eds), China's Local Public Finance in Transition, Lincoln Institute of Land Policy. 


\section{WORKING PAPERS}

The full series of Economics Department Working Papers can be consulted at www.oecd.org/eco/workingpapers/

1029 The declining competitiveness of French firms reflects a generalised supply-side problem (February 2013) by Hervé Boulhol and Patrizio Sicari

1028 Do the overall level and dispersion of socio-economic background measures explain France's gap in PISA scores?

(forthcoming) by Hervé Boulhol and Patrizio Sicari

1027 Labour market performance by age groups: a focus on France

(February 2013) by Hervé Boulhol and Patrizio Sicari

1026. Moving towards a single labour contract: pros, cons and mixed feelings

(February 2013) by Nicolas Lepage-Saucier, Juliette Schleich and Etienne Wasmer

1025. Boosting productivity in Australia

(January 2013) by Vassiliki Koutsogeorgopoulou and Omar Barbiero

1024. Housing, financial and capital taxation policies to ensure robust growth in Sweden

(January 2013) by Müge Adalet McGowan

1023. Labour market and social policies to foster more inclusive growth in Sweden

(January 2013) by Stéphanie Jamet, Thomas Chalaux and Vincent Koen

1022. Educational attainment and labour market outcomes in South Africa, 1994-2010 (January 2013) by Nicola Branson and Murray Leibbrandt

1021. Education quality and labour market outcomes in South Africa

(January 2013) by Nicola Branson and Murray Leibbrandt

1020. Do policies that reduce unemployment raise its volatility? Evidence from OECD countries

(January 2013) by Alain de Serres and Fabrice Murtin

1019. Slovakia: A catching up euro area member in and out of the crisis

(January 2013) by Jarko Fidrmuc, Caroline Klein, Robert Price and Andreas Wörgötter

1018. Improving the fiscal framework to enhance growth in an era of fiscal consolidation in Slovakia (January 2013) by Caroline Klein, Robert Price and Andreas Wörgötter

1017. Investing efficiently in education and active labour market policies in Slovakia (January 2013) by Caroline Klein

1016. The performance of road transport infrastructure and its links to policies (January 2013) by Henrik Braconier, Mauro Pisu and Debra Bloch

1015. The US labour market recovery following the great recession (January 2013) by Wendy Dunn 
1014. Why do Russian firms use fixed-term and agency work contracts?

(December 2012) by Larisa Smirnykh and Andreas Wörgötter

1013. The Equity implications of fiscal consolidation

(December 2012) by Lukasz Rawdanowicz, Eckhard Wurzel and Ane Kathrine Christensen

1012. The Dutch labour market: preparing for the future

(December 2012) by Mathijs Gerritsen and Jens Høj

1011. Reforming policies for the business sector to harvest the benefits of globalisation in the Netherlands

(December 2012) by Mathijs Gerritsen and Jens Høj

1010. Health care reform and long-term care in the Netherlands

(December 2012) by Erik Schut, Stéphane Sorbe and Jens Høj

1009. Enhancing the inclusiveness of the labour market in Belgium

(December 2012) by Jens Høj

1008. Reducing poverty in Estonia through activation and better targeting

(December 2012) by Sarah Flèche and Artur Radziwill

1007. Matching skills and jobs in Estonia

(December 2012) by Lilas Demmou

1006. Debt and macroeconomic stability: An overview of the literature and some empirics

(December 2012) by Douglas Sutherland and Peter Hoeller

1005. Debt and macroeconomic stability: Debt and the business cycle

(December 2012) by Volker Ziemann

1004. Debt and macroeconomic stability: Case studies

(December 2012) by Rossana Merola

1003. Debt and macroeconomic stability

(December 2012) by Douglas Sutherland, Peter Hoeller, Rossana Merola and Volker Ziemann

1002. Reducing greenhouse gas emissions in a cost effective way in Switzerland.

(December 2012) by Anita Wölfl and Patrizio Sicari

1001. Strengthening innovation in the United States

(November 2012) by David Carey, Christopher Hill and Brian Kahin

1000. Long-term growth scenarios

(January 2013) by Åsa Johansson, Yvan Guillemette, Fabrice Murtin, David Turner,

Giuseppe Nicoletti, Christine de la Maisonneuve, Philip Bagnoli, Guillaume Bousquet and Francesca Spinelli

999. Selected aspects of household savings in Germany - evidence from micro-data

(November 2012) by Christina Kolerus, Isabell Koske and Felix Hüfner 